Article

\title{
Effects of Pumice-Based Porous Material on Hydration Characteristics and Persistent Shrinkage of Ultra-High Performance Concrete (UHPC)
}

\author{
Kaizhi Liu ${ }^{1,2}$, Rui Yu ${ }^{1,3, *}$, Zhonghe Shui ${ }^{1,3}$, Xiaosheng $\mathrm{Li}^{1,2}$, Xuan Ling ${ }^{1,2}$, Wenhao $\mathrm{He}^{2}$, \\ Shuangqin $\mathrm{Yi}^{2}$ and Shuo $\mathrm{Wu}^{1}$ \\ 1 State Key Laboratory of Silicate Materials for Architectures, Wuhan University of Technology, \\ Wuhan 430070, China; liu03303116@126.com (K.L.); zhshui@whut.edu.cn (Z.S.); \\ li-xiaosheng@whut.edu.cn (X.L.); lingxuan@whut.edu.cn (X.L.); wushuo.phyche@hotmail.com (S.W.) \\ 2 School of Materials Science and Engineering, Wuhan University of Technology, Wuhan 430070, China; \\ 15730325018@163.com (W.H.); x3463973524@163.com (S.Y.) \\ 3 Wuhan University of Technology Advanced Engineering Technology Research Institute of Zhongshan, \\ Zhongshan 528437, China \\ * Correspondence: r.yu@whut.edu.cn; Tel.: +86-134-7609-5912
}

Received: 26 November 2018; Accepted: 17 December 2018; Published: 20 December 2018

\begin{abstract}
In this paper, two kinds of pumice particles with different diameters and water absorption rates are employed to substitute the corresponding size of river sands by volume fraction, and their effects on the hydration characteristics and persistent shrinkage of Ultra-High Performance Concrete (UHPC) are investigated. The obtained experimental results show that adopting a low dosage of $0.6-1.25 \mathrm{~mm}$ saturated pumice as the internal curing agent in UHPC can effectively retract the persistent shrinkage deformation of concrete without a decrease of strength. Heat flow calorimetry results demonstrate that the additional water has a retarding effect and promotes the hydration process. X-ray Diffraction (XRD) and Differential Thermal Gravimetry (DTG) are utilized to quantify the $\mathrm{Ca}(\mathrm{OH})_{2}$ content in the hardened paste, which can confirm that the external moisture could accelerate the early cement hydration and secondary hydration of active mineral admixtures. The $\mathrm{Ca} / \mathrm{Si}$ ratio of C-S-H calculated by the Energy Dispersive Spectrometer (EDS) reveals that the incorporation of wet pumice can transform the composition and structure of hydration products in its effective area.
\end{abstract}

Keywords: Ultra-High Performance Concrete (UHPC); long-term drying shrinkage; hydration characteristic; porous pumice; optimization

\section{Introduction}

UHPC (Ultra-high performance concrete), as a new type of cement-based material, is designed based on the principle of the closest packing between particles of each component with a very low water-to-binder ratio $(\mathrm{w} / \mathrm{b}<0.2)$ and a certain amount of reinforcing fibers [1-4]. Therefore, UHPC cement-based materials show great potential in applications which satisfy the requirements of structural engineering at a higher height, larger span, and heavier load [5-11]. Along with its excellent mechanical properties and durability, a strong continuous shrinkage deformation of the UHPC matrix can negatively affect its stability and reliability during the practical service life. This can be attributed to a rapid decrease in the relative humidity within the pores inside the UHPC system during the hydration process of cement at a relatively low $\mathrm{w} / \mathrm{b}$ [12-14]. Therefore, how to effectively settle the problem of the large volume contraction of UHPC has become a hot topic in current research. 
The accepted means to minimize the shrinkage of UHPC by employing internal curing carrier materials [15-19], expansive agents [20,21], shrinkage reducing agents [18,22,23], and other methods [24-26], can restrict the constriction development, especially its early self-shrinkage. However, the reduction of shrinkage by using an expansive agent alone is not recommendable due to its challenge in controlling the amount of swelling and occurrence time. A shrinkage reducing agent is often accompanied by the inhibition of early strength development and further deterioration of mechanical properties, if it has poor compatibility with chemical admixtures [27]. In contrast, an internal curing (IC) mechanism is considered to be a reasonable solution to fundamentally and effectively control UHPC contraction. Nowadays, most IC agents utilized in UHPC are super absorbent polymers and various types of lightweight aggregates (LWAs). It has been revealed that super absorbent polymers can significantly bate the growth of autogenous shrinkage of UHPC, and even fully compensate for the early contraction of concrete $[15,28,29]$. Nevertheless, the introduction of super absorbent polymers will negatively influence the compactness of UHPC and increase the porosity, resulting in degradation of the mechanical properties and durability of concrete, which are both important indicators of UHPC. Pre-wetting LWA is a kind of potential IC carrier material that can also delay the self-desiccation of UHPC through the slow-release effect of water, which has excellent volume stability during water absorption and release. Hence, the pre-wetting LWA can be potentially treated as an effective material to minimize the UHPC shrinkage based on experimental and practical points of view.

The commonly applied LWAs in concrete as IC agents include expanded clay, perlite, shale, other types of ceramsite, tuff, and pumice, etc. Philleo's experiment found that the pre-wetted porous ceramic pellets could effectively reduce the self-shrinkage deformation of concrete, and explicitly put forward the concept of IC for the first time [30]. Bentz et al. [31-33] confirmed that the moisture introduced by LWA could not only restrain the contraction and cracking of concrete, but also improve the hydration degree of the surrounding mortar and intensify the strength. Besides, they proposed the formula for calculating the minimum amount of LWA for IC. Bentur et al. [34] showed that there was a significant correlation between the evolution of shrinkage performance and water content of pre-wetting ceramsite in high strength concrete. They found that the saturated ceramsite replacing ordinary aggregates by a volume fraction of $25 \%$ would completely offset the shrinkage and even swell. Akcay et al. and Henkensiefken et al. [35-37] demonstrated that the size of the aqueous LWA particles has an obvious influence on the effective range and efficiency of IC, and smaller granules were preferred. Henkensiefken et al. and Lura et al. [38,39] suggested increasing the substitution rate of soaked LWA, which could improve the relative humidity inside the paste and postpone the self-desiccation. Zhutovsky et al. [40-42] scientifically described the effect of exploiting pumice as the IC agent in high strength concrete. They showed that there was an optimal size distribution range of pumice particles in high strength concrete, and oversized or undersized particles would weaken the IC effect. The influence of incorporating saturated pumice on the evolution of total contraction deformation of high strength concrete within 100 days was related to the $\mathrm{w} / \mathrm{b}$ of the system, while lowering $\mathrm{w} / \mathrm{b}$ was beneficial to the dry shrinkage. Moreover, when adding wet pumice, the extent of hydration and total porosity of concrete increased, which might lead to impairing the characteristics of the densification matrix. Other scholars [43-47] also expressed concern about the potential negative effects of the introduction of water-absorbing LWAs on the strength, durability, and contraction distortion of concrete in a drying environment. In particular, RILEM TC 196-ICC [48] emphasized that adequate attention should be paid to the continuous shrinkage of IC concrete under dry conditions.

At present, there are few studies on LWAs as the IC carrier materials of UHPC. Suzuki et al. [49] claimed that using a porous ceramic-coarse aggregate as the IC agent of UHPC ( $w / b=0.15)$ could slightly improve the compressive strength of concrete and depress autogenous shrinkage strain, and the effect on drying shrinkage was negligible. Van et al. [17] expounded that the moisture provided by the humid rice husk ash could not only delay the start-up time of the relative humidity drop inside UHPC, but also promote the continuous hydration of the cementitious system, thereby improving the mechanical properties and volume stability of concrete. The results of Wang et al. [50] showed 
that the incorporation of wet coral sand would clearly condense the self-shrinkage of UHPC, and the total contraction within seven days decreased by $53.9 \%$. Meanwhile, there was a negative correlation between the development of concrete strength and the level of substitution. Meng and Khayat. [19] superseded river sand by volume fraction with $25 \%$ pre-saturated expanded shale, which could reduce the autogenous shrinkage deformation of UHPC by $25.4 \%$ and increase the compressive strength by $21.5 \%$ in 28 days. Nevertheless, the current concerns on the IC effect of LWAs on UHPC shrinkage are more focused on the early age (first $7 \mathrm{~d}$ or most up to $28 \mathrm{~d}$ ), and the possible adverse effects from extraneous water brought in by the LWAs on the long-term persistent shrinkage deformation behavior under drying condition are usually ignored. In addition, the investigations regarding the effect of the gradation of LWA particles and content of extra water on the hydration process and hydration products in UHPC are limited.

Consequently, in this study, a typical LWA (pumice) is included in the production of UHPC, and the effects of extra water (from pre-wetting LWA) on the macro behaviors, including contraction continuous evolution under low humidity surroundings and the hydration of the composites cementitious system in UHPC, are investigated. The working performance, mechanical properties, and dry shrinkage of the developed UHPC are measured by standardized test methods, while microscopic analysis as hydration heat, XRD, DTG, and EDS are used to clarify some hydration characteristics.

\section{Materials and Methods}

\subsection{Materials}

OPC 52.5 cement (Huaxin Cement Co., Ltd., Huangshi, China), first grade fly ash (FA) (Huaneng Yangluo Power Plant, Wuhan, China), and silica fume (SF) (Southeast Star Technology Development Co., Ltd., Chengdu, China) are used as the active powders in this work and the XRF analysis results are shown in Table 1. Continuously graded river sand (Wuhan, China) and pumice particles (Changbai Mountain, China) $(0-0.6 \mathrm{~mm}$ and $0.6-1.25 \mathrm{~mm})$ are added as fine aggregates. A highly effective polycarboxylate super plasticizer (SP) (Sobute New Materials Co., Ltd., Nanjing, China), which has a solid content of $20 \%$ and a water reduction rate of $40 \%$, is also added.

Table 1. Chemical compositions of the employed cementitious materials (\%).

\begin{tabular}{ccccccccccc}
\hline Compositions & $\mathbf{N a}_{\mathbf{2}} \mathbf{O}$ & $\mathbf{M g O}$ & $\mathbf{A l}_{\mathbf{2}} \mathbf{O}_{\mathbf{3}}$ & $\mathbf{S i O}_{\mathbf{2}}$ & $\mathbf{P}_{\mathbf{2}} \mathbf{O}_{\mathbf{5}}$ & $\mathbf{S O}_{\mathbf{3}}$ & $\mathbf{K}_{\mathbf{2}} \mathbf{O}$ & $\mathbf{C a O}$ & $\mathbf{F e}_{\mathbf{2}} \mathbf{O}_{\mathbf{3}}$ & $\mathbf{L O I}$ \\
\hline Cement & 0.09 & 1.61 & 4.18 & 19.20 & 0.09 & 3.35 & 0.78 & 64.93 & 3.32 & 2.49 \\
$\mathrm{SF}$ & 0.13 & 0.47 & 0.25 & 94.65 & 0.17 & 0.69 & 0.84 & 0.36 & 0.15 & 2.29 \\
$\mathrm{FA}$ & 0.33 & 0.23 & 38.01 & 46.44 & 0.06 & 0.69 & 0.88 & 7.50 & 3.12 & 2.79 \\
\hline
\end{tabular}

Pumice stone is well-known as a natural porous mineral material with a well-developed pore structure and an environment scanning electron microscope (ESEM) (FEI, Hillsboro, OR, USA) photomicrograph of it is shown in Figure 1. Pumice has a high porosity (more than $50 \%$ ) and its pore framework is dominated by micron-sized slender tubular channels, and almost all of them are interconnected [35,51-54]. This typical conformation determines that it can be exploited as an efficient IC vector. The mineral phases are analyzed by XRD (Bruker, Karlsruhe, Germany) and the results are presented in Figure 2, which reveals that the main structure of pumice is $\mathrm{Na}+, \mathrm{K}+$ type amorphous phase feldspar with a brilliant stability (A: PDF (ICDD) 10-0393, S: PDF (ICDD) 10-0357, Q: PDF (ICDD) 46-1045). The main chemical components of pumice are $\mathrm{SiO}_{2} 70.55 \%, \mathrm{Al}_{2} \mathrm{O}_{3} 11.21 \%, \mathrm{Na}_{2} \mathrm{O}$ $4.79 \%, \mathrm{Fe}_{2} \mathrm{O}_{3} 4.57 \%, \mathrm{~K}_{2} \mathrm{O} 3.76 \%$, and $\mathrm{CaO} 0.81 \%$, which are provided by XRF. Meanwhile, the apparent densities of $0-0.6 \mathrm{~mm}$ and $0.6-1.25 \mathrm{~mm}$ pumice are $1.08 \mathrm{~g} / \mathrm{cm}^{3}$ and $0.59 \mathrm{~g} / \mathrm{cm}^{3}$, respectively, and the corresponding saturated water absorption rates of them are $77.9 \%$ and $66.6 \%$, as determined by the tissue wiping method $[55,56]$. 

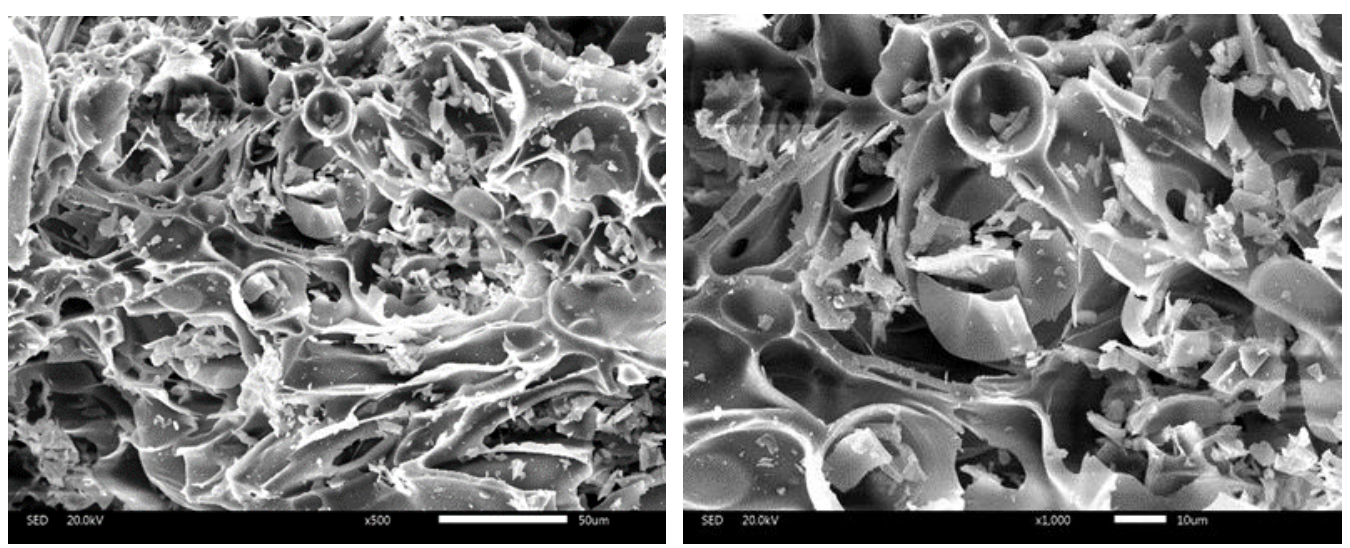

Figure 1. ESEM photomicrographs of the employed pumice stone.

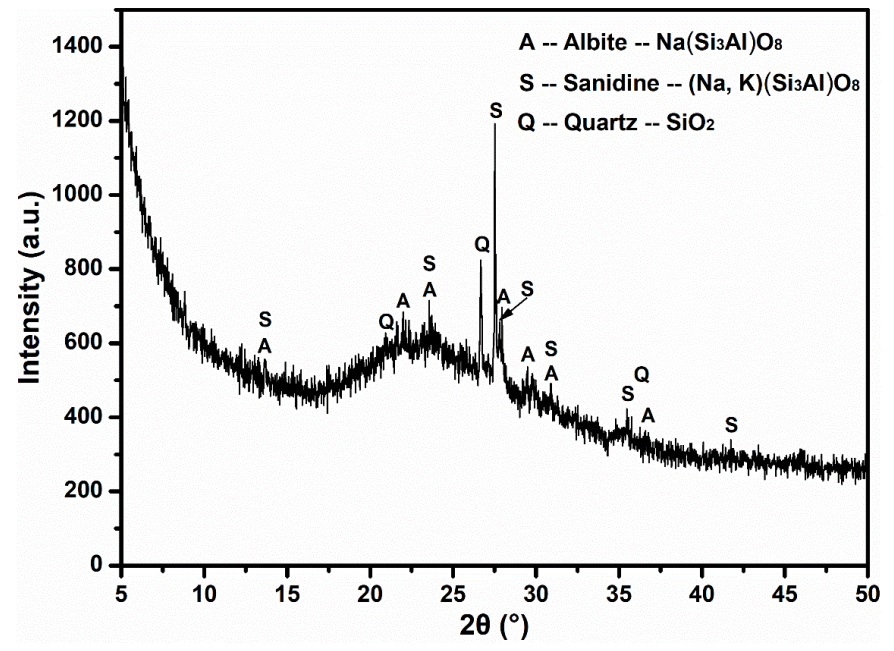

Figure 2. XRD pattern of natural pumice stone.

\subsection{Experimental Methodology}

\subsubsection{Design Method}

The revised Andreasen-Andersen (A\&A) model is widely applied in the optimization design of the UHPC mix ratio. Studies confirmed that the optimal range of the distribution coefficient $(\mathrm{q})$ is $0.22 \sim 0.25[50,57,58]$, and the value of $q$ is selected as 0.23 in this paper.

In order to retain the accumulation state of the UHPC system, the pumice replaces the same-grain river sand with a certain volume ratio. According to the measured particle size distribution of the active powders and the two fine aggregates, the method of least squares (Equation (1)) is used to evaluate the close packing state of granules in UHPC, and the reasonable mixture ratio design scheme of the matrix is exhibited in Table 2, where $\mathrm{C} 0$ represents the control group; $\mathrm{U}$ and $\mathrm{S}$ indicate the water absorption state of the pumice, where $U$ represents unsaturation and $S$ represents saturation; and $\mathrm{P}_{1}$ and $\mathrm{P}_{2}$ represent the $0-0.6 \mathrm{~mm}$ and $0.6-1.25 \mathrm{~mm}$ pumice particle substitution system, respectively.

$$
R S S=\frac{\sum_{i-1}^{n}\left(P_{\text {mix }}\left(D_{i}^{i+1}\right)-P_{\text {tar }}\left(D_{i}^{i+1}\right)\right)^{2}}{n}
$$

where $D_{i}^{i+1}, n, P_{\text {mix }}$ and $P_{\text {tar }}$ denote some gradation of particle size $(\mu \mathrm{m})$, the number of chosen particle sizes, the designed mix, and the target curve, respectively. RSS is sum of the squares of the residuals, which represents the proximity of the designed mix and target curve. 
Table 2. Recipe of the designed UHPC combined with damp pumice particles $\left(\mathrm{kg} / \mathrm{m}^{3}\right)$.

\begin{tabular}{|c|c|c|c|c|c|c|c|c|c|}
\hline \multirow{2}{*}{ Group } & \multirow{2}{*}{ Cement } & \multirow{2}{*}{ FA } & \multirow{2}{*}{ SF } & \multicolumn{2}{|c|}{ River Sand } & \multicolumn{2}{|c|}{ Damp Pumice } & \multirow{2}{*}{ Water } & \multirow{2}{*}{ SP } \\
\hline & & & & $0-0.6$ & $0.6-1.25$ & $0-0.6$ & $0.6-1.25$ & & \\
\hline C0 & 750 & 200 & 144 & 770 & 220 & 0 & 0 & 175 & 31 \\
\hline $\mathrm{UP}_{1} \mathrm{C} 10$ & 750 & 200 & 144 & 693 & 220 & 37.08 & 0 & 175 & 31 \\
\hline $\mathrm{UP}_{1} \mathrm{C} 20$ & 750 & 200 & 144 & 616 & 220 & 74.16 & 0 & 175 & 31 \\
\hline $\mathrm{UP}_{1} \mathrm{C} 30$ & 750 & 200 & 144 & 539 & 220 & 111.24 & 0 & 175 & 31 \\
\hline $\mathrm{UP}_{2} \mathrm{C} 10$ & 750 & 200 & 144 & 770 & 198 & 0 & 6.00 & 175 & 31 \\
\hline $\mathrm{UP}_{2} \mathrm{C} 20$ & 750 & 200 & 144 & 770 & 176 & 0 & 12.00 & 175 & 31 \\
\hline $\mathrm{UP}_{2} \mathrm{C} 30$ & 750 & 200 & 144 & 770 & 154 & 0 & 18.00 & 175 & 31 \\
\hline $\mathrm{SP}_{1} \mathrm{C} 10$ & 750 & 200 & 144 & 693 & 220 & 55.43 & 0 & 175 & 31 \\
\hline $\mathrm{SP}_{1} \mathrm{C} 20$ & 750 & 200 & 144 & 616 & 220 & 110.86 & 0 & 175 & 31 \\
\hline $\mathrm{SP}_{1} \mathrm{C} 30$ & 750 & 200 & 144 & 539 & 220 & 166.29 & 0 & 175 & 31 \\
\hline $\mathrm{SP}_{2} \mathrm{C} 10$ & 750 & 200 & 144 & 770 & 198 & 0 & 8.38 & 175 & 31 \\
\hline $\mathrm{SP}_{2} \mathrm{C} 20$ & 750 & 200 & 144 & 770 & 176 & 0 & 16.76 & 175 & 31 \\
\hline $\mathrm{SP}_{2} \mathrm{C} 30$ & 750 & 200 & 144 & 770 & 154 & 0 & 25.14 & 175 & 31 \\
\hline
\end{tabular}

The closest stacking curves of the raw materials emerged in Figure 3. It is shown that although the gradation of pumice particles in the same size range is different from that of river sands, no obvious deterioration of the accumulation state between the particles can be observed, whose form are still in a tight status.

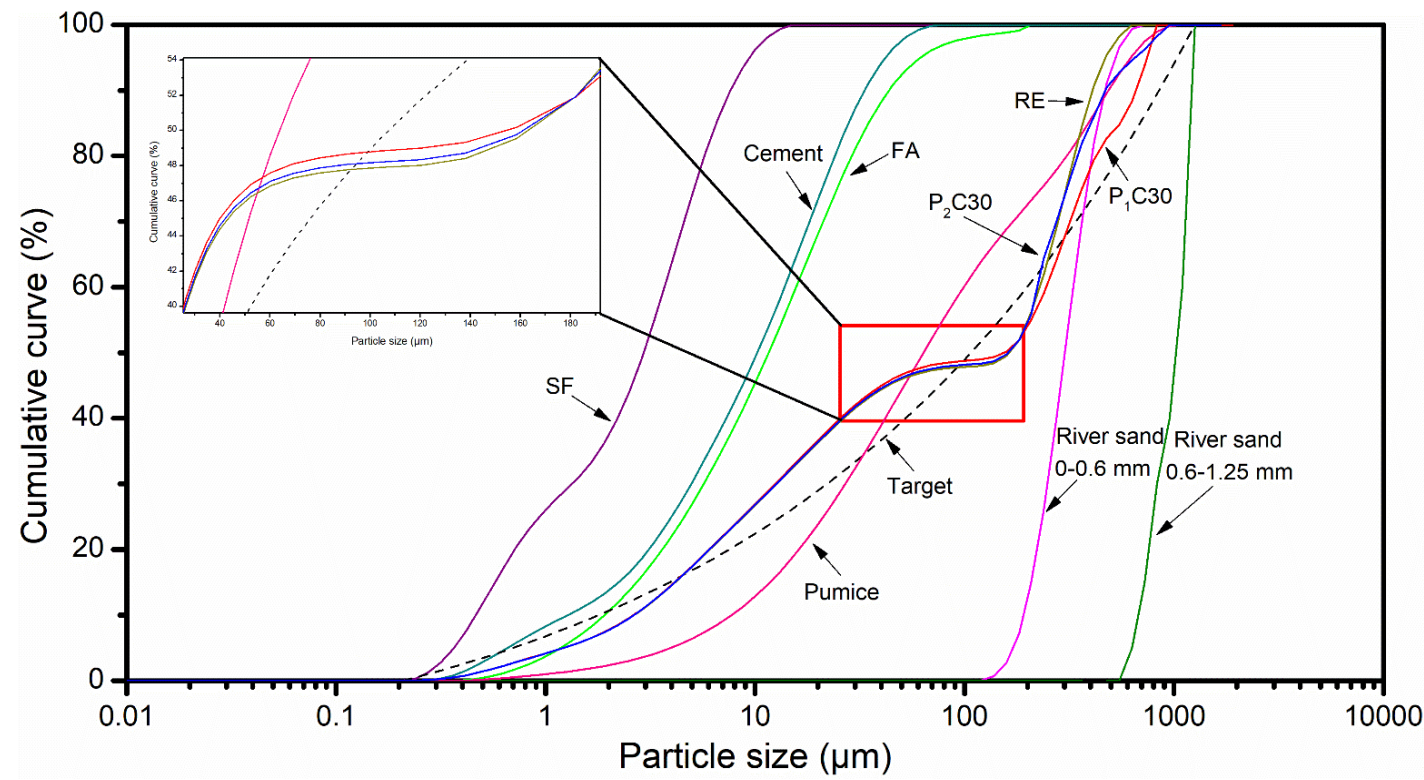

Figure 3. Particle size distributions (PSDs) of the crude materials, the target, and optimized grading curves of the composites on account of optimized pre-wetting pumice substances.

\subsubsection{Flowability}

The fluidity of the fresh UHPC paste is evaluated by GB/T 2419-2005 [59]. The test die includes a truncated cone mold and a pattern sleeve, wherein the mould size is as follows: the inner diameters of the upper and lower ports are $70 \mathrm{~mm}$ and $100 \mathrm{~mm}$, respectively; and the outer diameter of the lower mouth and height are $120 \mathrm{~mm}$ and $60 \mathrm{~mm}$, respectively.

\subsubsection{Mechanical Properties}

UHPC compressive and flexural strength is tested according to GB/T 17671-1999 [60]. The sample size is $40 \mathrm{~mm} \times 40 \mathrm{~mm} \times 160 \mathrm{~mm}$, and the samples are kept in water at a temperature of $20 \pm 2{ }^{\circ} \mathrm{C}$. In the experiment, six specimens per mix-age are tested. 


\subsubsection{Drying Shrinkage}

The measurement of UHPC drying shrinkage is based on JC/T 603-2004 [61]. Each group is formed of three samples of $25 \mathrm{~mm} \times 25 \mathrm{~mm} \times 280 \mathrm{~mm}$, and the test blocks is kept in $20 \pm 2{ }^{\circ} \mathrm{C}$ water for seven days after demolding. After maintenance, the initial length of the specimens is recorded as $\mathrm{L}_{0}$, and the pieces are transferred into the dry shrinkage curing box with a condition of temperature of $20 \pm 2{ }^{\circ} \mathrm{C}$ and humidity of $60 \pm 2 \%$ as the "time zero", and the length $\mathrm{L} x$ is measured at the corresponding time.

\subsubsection{Hydration Process}

To evaluate the effect of extra water introduced by the pre-wetting pumice on the cement hydration kinetic in the UHPC composite system, a heat flow calorimetry modeled TAM AIR is employed. The paste is strictly designed according to the recipes; simultaneously, the rate of heat liberation and total heat within $72 \mathrm{~h}$ are monitored.

\subsubsection{XRD}

The hydration products of UHPC are characterized by a D8 Advance diffractometer with $\mathrm{Cu} \mathrm{K} \alpha$ radiation, a step size of $0.019^{\circ} 2 \theta / \mathrm{step}$, a measuring time of $141.804 \mathrm{~s} / \mathrm{step}$, a start position of $5^{\circ}(2 \theta)$, and an end position of $50^{\circ}(2 \theta)$.

\subsubsection{DTG}

The standard ground sample powders are subjected to thermogravimetric analysis using a NETZSCH STA 2500 synchronous thermal analyzer at a heating rate of $10^{\circ} \mathrm{C} / \mathrm{min}$ up to $1000{ }^{\circ} \mathrm{C}$.

\subsubsection{ESEM-EDS}

The micro-domain morphology and structure of the samples' surface are observed by a QUANTA FEG 450 field emission ESEM. At the same time, the EDS analysis can interpret the micro-area components, and the intelligent quantitative results provided by eZAF help to effectively evaluate the atomic ratio of the skin layer elements.

\section{Results and Discussion}

\subsection{Fresh Behaviors}

The relationship between the fluidity of the fresh paste and the amount of extra water introduced under different mixing ratios is shown in Table 3. The given results indicate that under the same substitution ratio, there is a good positive correlation between the liquidity and the content of water imported; that is, the more water that is introduced, the greater the flowability of the paste. This is attributed to the increase of internal moisture in UHPC, which means that more water participates in the lubrication of the particles, resulting in the increase of the fluidity of the newly poured mortar. Compared with the behavior of the control group, the liquidity of the UHPC compound system is determined by the role of wet pumice particles (whether continuously injected water into the paste or siphon free moisture from the paste during the mixing process). As the water absorption of the pumice particles does not reach saturation, the mortar fluidity will only increase when the volume substitution fraction reaches $30 \%$, whose liquidity exceeds $200 \mathrm{~mm}(\mathrm{C} 0=183 \mathrm{~mm})$. When the replacement grade is less than $20 \%$, the flowability drops to a minor extent, with a minimum of $165 \mathrm{~mm}$. When the pumice pellets reach a water saturated state, the paste fluidity is controlled by the amount of water introduced. If the content of extra water exceeds $10 \mathrm{~g}$, the mobility of the paste will improve, and the greater the amount of water introduced, the greater the fluidity of the new mixture. When the external water content reaches $72.9 \mathrm{~g}$, the flow value reaches the maximum value of $374 \mathrm{~mm}$, attaining $204.4 \%$ of the control group. 
Table 3. Fluidity of the designed UHPC with different amounts of extra water introduced by wet pumice.

\begin{tabular}{ccccc}
\hline \multirow{2}{*}{ Group } & \multirow{2}{*}{ Extra Water } & \multicolumn{2}{c}{ w/b } & \multirow{2}{*}{ Fluidity $(\mathbf{m m})$} \\
\cline { 3 - 4 } & & Free & Total & \\
\hline $\mathrm{C} 0$ & 0 & & 0.1826 & 183 \\
$\mathrm{UP}_{1} \mathrm{C} 10$ & 5.9 & & 0.1880 & 167 \\
$\mathrm{UP}_{1} \mathrm{C} 20$ & 11.8 & & 0.1934 & 173 \\
$\mathrm{UP}_{1} \mathrm{C} 30$ & 17.7 & & 0.1988 & 214 \\
$\mathrm{UP}_{2} \mathrm{C} 10$ & 0.96 & & 0.1835 & 165 \\
$\mathrm{UP}_{2} \mathrm{C} 20$ & 1.92 & & 0.1844 & 180 \\
$\mathrm{UP}_{2} \mathrm{C} 30$ & 2.88 & 0.1826 & 0.1853 & 201 \\
$\mathrm{SP}_{1} \mathrm{C} 10$ & 24.3 & & 0.2048 & 269 \\
$\mathrm{SP}_{1} \mathrm{C} 20$ & 48.6 & & 0.2271 & 345 \\
$\mathrm{SP}_{1} \mathrm{C} 30$ & 72.9 & & 0.2493 & 374 \\
$\mathrm{SP}_{2} \mathrm{C} 10$ & 3.35 & & 0.1857 & 147 \\
$\mathrm{SP}_{2} \mathrm{C} 20$ & 6.7 & & 0.1888 & 181 \\
$\mathrm{SP}_{2} \mathrm{C} 30$ & 10.05 & & 0.1918 & 186 \\
\hline
\end{tabular}

\subsection{Mechanical Properties}

The compressive and flexural strengths of the designed UHPC with different formulas are shown in Figures 4 and 5, respectively. The compressive strength results show that the addition of soaked pumice reduces the compressive strength of UHPC after $28 \mathrm{~d}$ curing as a whole, and the average strength of each group is $91.2 \%$ of $\mathrm{C} 0$, while the maximum compressive strength loss rate $\left(\mathrm{UP}_{2} \mathrm{C} 20\right)$ is $20.6 \%$. Among them, the strength development of $\mathrm{UP}_{1}$ and $\mathrm{UP}_{2}$ substitution systems has a similar law; that is, the strength decreases as the content of extra water increases. The distinction is that the average $28 \mathrm{~d}$ compressive strength of $\mathrm{UP}_{1}$ groups is $5.6 \%$ lower than that of $\mathrm{C} 0$, while that of $\mathrm{UP}_{2}$ is $18.4 \%$. For the groups of $0-0.6 \mathrm{~mm}$ pumice particles to replace the homologous river sands, as the content of introduced water is in the range of $17.7 \sim 48.6 \mathrm{~g}\left(\mathrm{UP}_{1} \mathrm{C} 30, \mathrm{SP}_{1} \mathrm{C} 10\right.$, and $\left.\mathrm{SP}_{1} \mathrm{C} 20\right)$, the compressive strength of each age has obvious loss. Meanwhile, the amount of extra water is less than $11.8 \mathrm{~g}\left(\mathrm{UP}_{1} \mathrm{C}_{10}\right.$, $\left.\mathrm{UP}_{1} \mathrm{C} 20\right)$ or up to $72.9 \mathrm{~g}\left(\mathrm{SP}_{1} \mathrm{C} 30\right)$, the compressive strength loss at $28 \mathrm{~d}$ is kept at a low level, and even a slight improvement can be observed. For that $0.6-1.25 \mathrm{~mm}$ pumice substitution system, the key factor determining the compressive strength of UHPC is the water absorption state of pumice. If the pumice granules do not reach the saturated water absorption, the strength is significantly depressed. The strength can be held at a similar gradation as the control group while the pumice particles are full of water.

The flexural strength results show that the flexural strengths of the $\mathrm{SP}_{1} \mathrm{C} 20$ and $\mathrm{SP}_{1} \mathrm{C} 30$ groups with a water content exceeding $48.6 \mathrm{~g}$ express a downward trend compared with the control group. In addition to the above both groups, the bending strength performance of other recipes embodies the same regular pattern, which is that the bending strength decreases with increasing extra water intake within a uniform substitution system, which remains notably higher than that of $\mathrm{C} 0$. The details can be inducted as follows: the flexural strength of the group blended with damp pumice after $1 \mathrm{~d}$ is significantly lower than that of $\mathrm{C} 0$, with an average value of $80.8 \%$. It grows rapidly within $1 \sim 3 \mathrm{~d}$ and almost completely exceeds that of $\mathrm{C} 0$ at $3 \mathrm{~d}$, with an average of $113.5 \%$. By $28 \mathrm{~d}$, the average bending strength of each group reaches $129.6 \%$ compared with $\mathrm{C} 0$, and the highest value achieves $157.7 \%\left(\mathrm{UP}_{1} \mathrm{C} 10\right)$. 


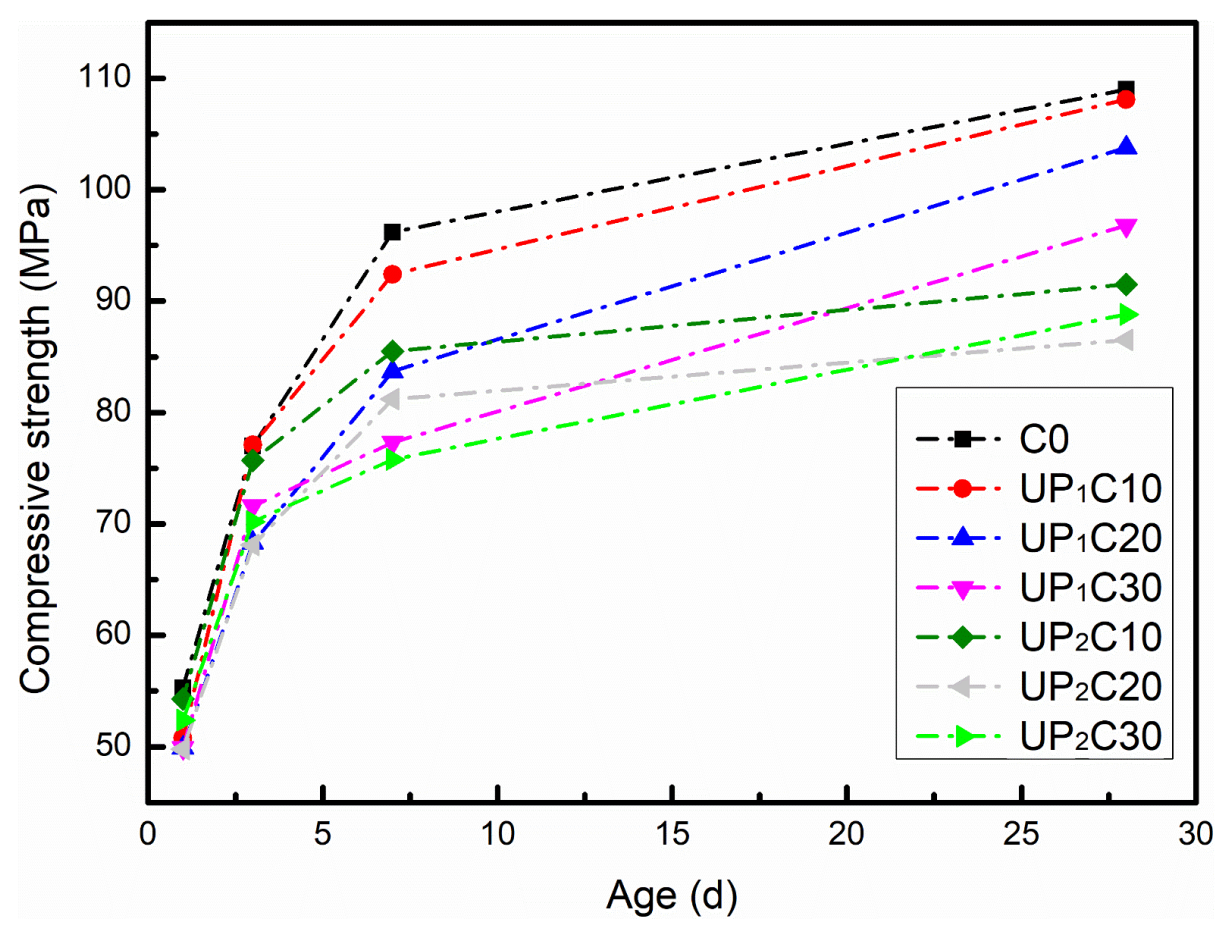

(a)

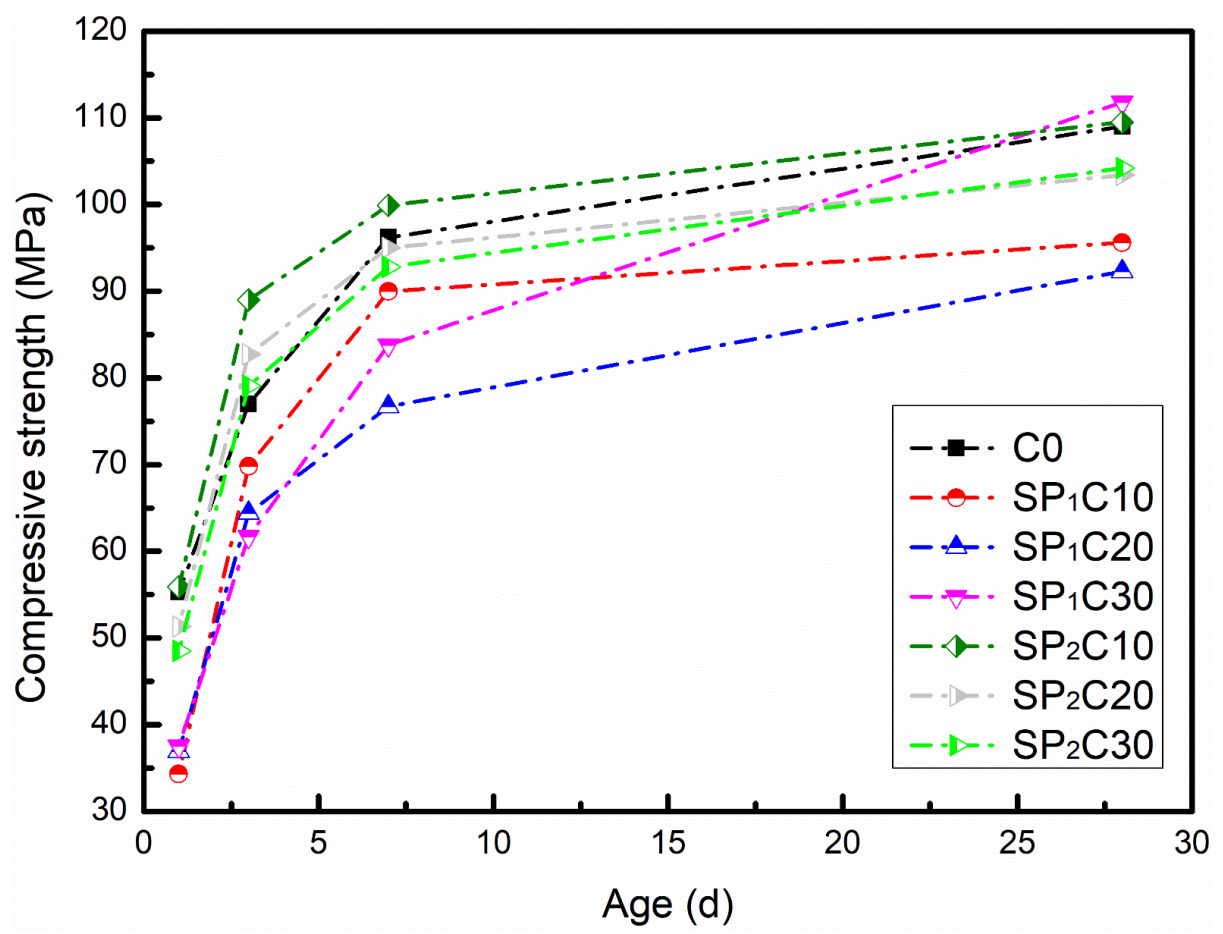

(b)

Figure 4. Compressive strength development of UHPC combined with water absorption pumice: (a) unsaturated pumice substitution; (b) saturated pumice substitution. 


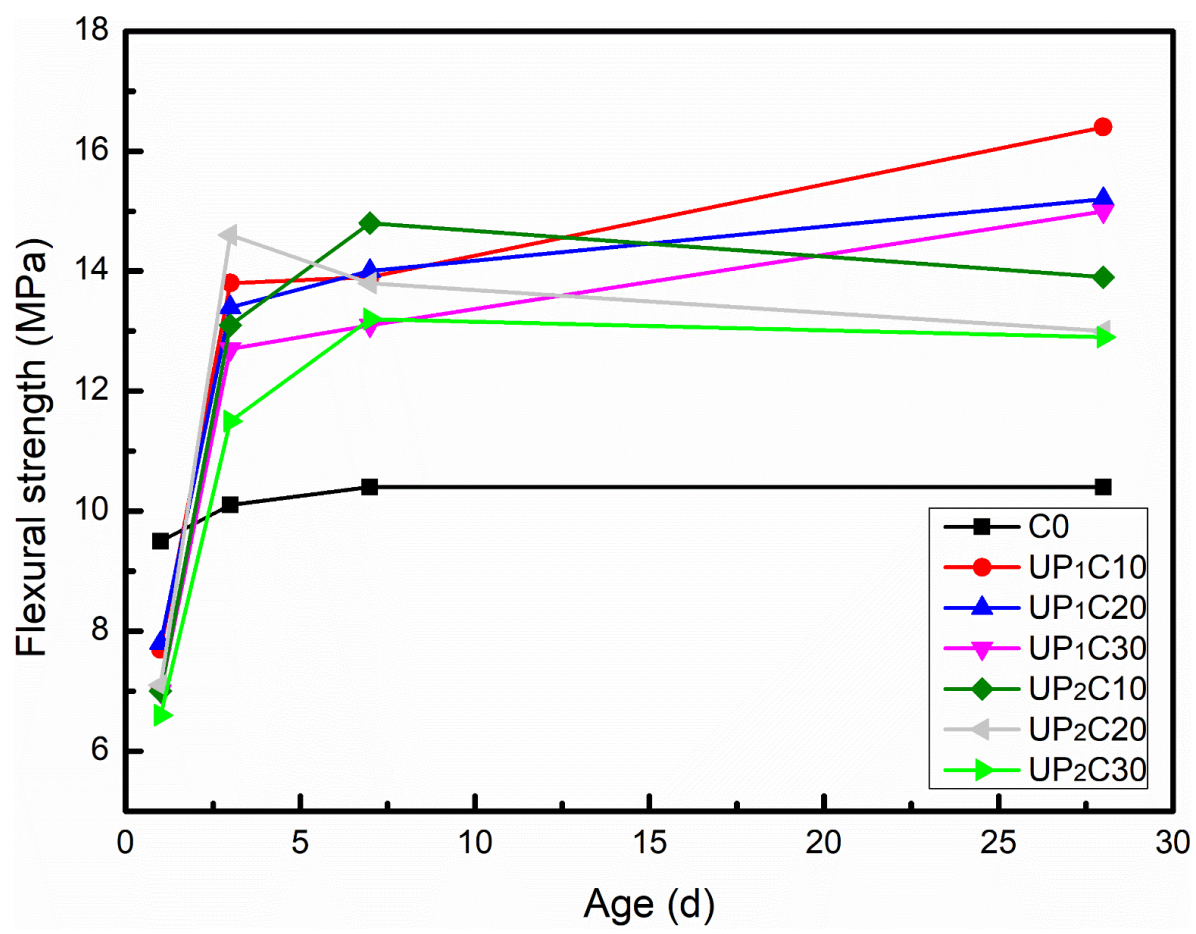

(a)

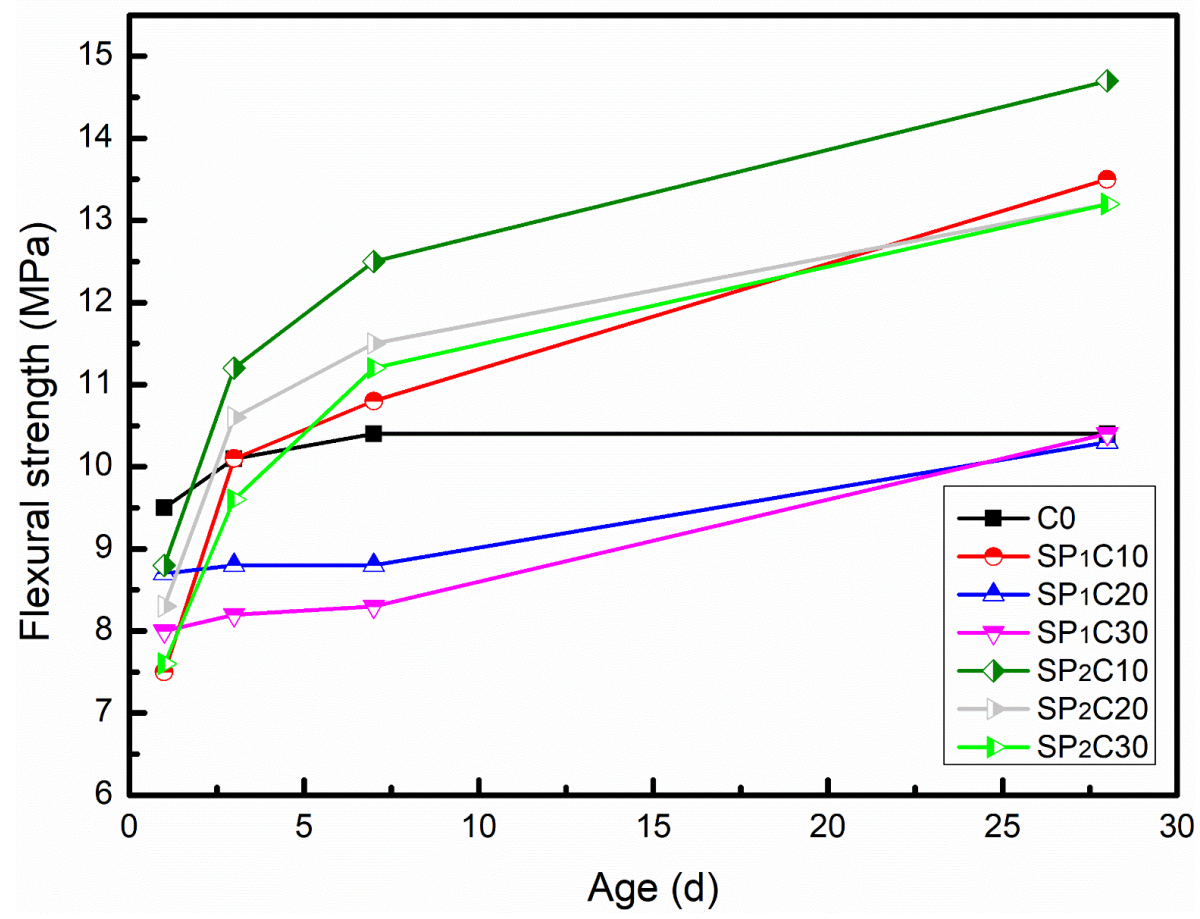

(b)

Figure 5. Flexural strength variation of UHPC combined with water absorption pumice: (a) unsaturated pumice substitution; (b) saturated pumice substitution.

The incorporation of pre-moistened pumice has both positive and negative effects on the development of UHPC mechanical properties. Among them, the positive effect is that the sustained release of moisture by the wet pumice will continuously promote the hydration of the unhydrated 
cement particles and secondary hydration of reactive powders (SF and FA) in the cementitious system and then enhance the gelling ability, whose contribution to the development of strength mainly affects the later stage. The negative effect comes from two aspects: primarily, the water released from the pumice pellets will cause the early actual $\mathrm{w} / \mathrm{b}$ of the system to rise, thereby affecting the porosity and types of hydration products, which brings a reduction of strength [62]. Secondly, the elastic modulus and crushing value of the pumice particles are clearly lower than those of natural river sand, and the fine mineral aggregates are destroyed under the action of external pressure or impact force, which leads to failure of the specimen $[52,54,63]$. In a word, the characteristic development of mechanical properties of pumice-based UHPC is a reflection of which effect dominates.

\subsection{Persistent Shrinkage Deformation}

The drying shrinkage curves of UHPC designed with different mix ratios are presented in Figure 6. Actually, the trend of drying shrinkage development is the collective result of the combined action of autogenous shrinkage after seven days and continuous dry shrinkage deformation in the later low humidity environment of concrete. Thus, the curves reflect the sight of the total shrinkage. The given information is that the drying shrinkage evolution characteristics of the UHPC system compounding damp pumice are significantly different from those of the control group. The dry shrinkage develops with a uniform growth in $\mathrm{C} 0$ within seven days, and the contraction behavior basically disappears and reaches a volume stable state after that. The first seven days of shrinkage development of UHPC with damp pumice is also swift, but the rate then gradually decreases, and the test piece continues to contract within $7 \mathrm{~d} \sim 160 \mathrm{~d}$. The constriction development of concrete is related to the moisture migration and pore structure of concrete $[64,65]$. The $\mathrm{w} / \mathrm{b}$ in UHPC is extremely low, and the moisture is quickly consumed in the early stage of hydration, resulting in a rapid decline in the relative humidity inside the system. Therefore, regardless of whether the concrete introduces an IC agent, its early (within $7 \mathrm{~d}$ ) shrinkage will increase quickly. UHPC has a low porosity and dense architecture, which makes it difficult to exchange moisture with the outside surroundings. Consequently, the $\mathrm{C} 0$ group can maintain a relatively stable evolution state after rapid development in the early stage. After being mixed with the humid pumice, the water slow-release effect of the pumice "tank" can effectively delay the decline of the internal relative humidity. Besides, the pumice pore structure has the function of retaining moisture, and restrains the diffusion of water to the outside. The effects of both mentioned above are superimposed, and the rate of contraction development in the UHPC within $7 \mathrm{~d}$ of adding the wet pumice is reduced. The release of water from the pumice in the concrete is a continuous process, and the moisture will increase the actual $\mathrm{w} / \mathrm{b}$ of the cementitious system, resulting in a raise in the total water capacity and porosity, which will elevate the permeability of UHPC [42]. At the same time, the pore structure of the porous pumice itself may also broaden the channels communicating with the external world. Thus, the drying shrinkage distortion of the UHPC combining the water-absorbing pumice will last for a long time.

The drying shrinkage of $C 0$ after $1 \mathrm{~d}, 7 \mathrm{~d}, 34 \mathrm{~d}$, and $160 \mathrm{~d}$ is $118 \mu \varepsilon, 408 \mu \varepsilon, 416 \mu \varepsilon$, and $422 \mu \varepsilon$, respectively. Compared with the control group, the contraction value of the designed UHPC with pre-wetted pumice at $1 \mathrm{~d}$ is increased, and the promotion of each compounding system is $28.0 \%, 43.2 \%$, and $55.9 \%$ with $\mathrm{UP}_{1} \mathrm{C} 10 \sim \mathrm{UP}_{1} \mathrm{C} 30 ; \mathrm{UP}_{2} \mathrm{C} 10 \sim \mathrm{UP}_{2} \mathrm{C} 30$ is $22.0 \%, 30.5 \%$, and $5.1 \% ; \mathrm{SP}_{1} \mathrm{C} 10 \sim \mathrm{SP}_{1} \mathrm{C} 30$ is $15.3 \%, 50.0 \%$, and $81.4 \%$; and $\mathrm{SP}_{2} \mathrm{C} 10 \sim \mathrm{SP}_{2} \mathrm{C} 30$ is $5.1 \%, 22.0 \%$, and $105.1 \%$, respectively. The analysis results indicate that the development of the shrinkage of the complex UHPC within $1 \mathrm{~d}$ is not directly related to the quantity of extra water, and the soaked pumice particles of $0.6-1.25 \mathrm{~mm}$ are more sensitive to drying shrinkage than those of $0-0.6 \mathrm{~mm}$. The content of foreign water by $\mathrm{SP}_{1} \mathrm{C} 10$ is 24.3 $\mathrm{g}$, and the constriction is increased by $15.3 \%$ compared with $\mathrm{C} 0$. Oppositely, the amount of water introduced by $\mathrm{SP}_{2} \mathrm{C} 20$ is $6.7 \mathrm{~g}$, but the corresponding shrinkage value is increased by $22.0 \%$. The extent to which the contraction characteristics of the concrete are affected is determined by the actual water participation in hydration that can effectively promote a reaction in the very early period. In fact, this process is related to the water release behavior of water-absorbing pumice grains in the interior of 
UHPC. The smaller the particle size of pumice after crushing, the lower the proportion of coarse holes and the connectivity in the pore structure [41]. It is generally believed that the water release behavior of the pore structure has a higher priority for the one with a larger diameter, which means that the larger beads have a faster water release rate and higher efficiency [66-68]. Under the same conditions, the size of 0.6-1.25 mm pumice granules can supply more water for the IC. In addition, the greater scale of the "miniature reservoir" that affects the effective area of hydration is more expansive $[63,69,70]$.

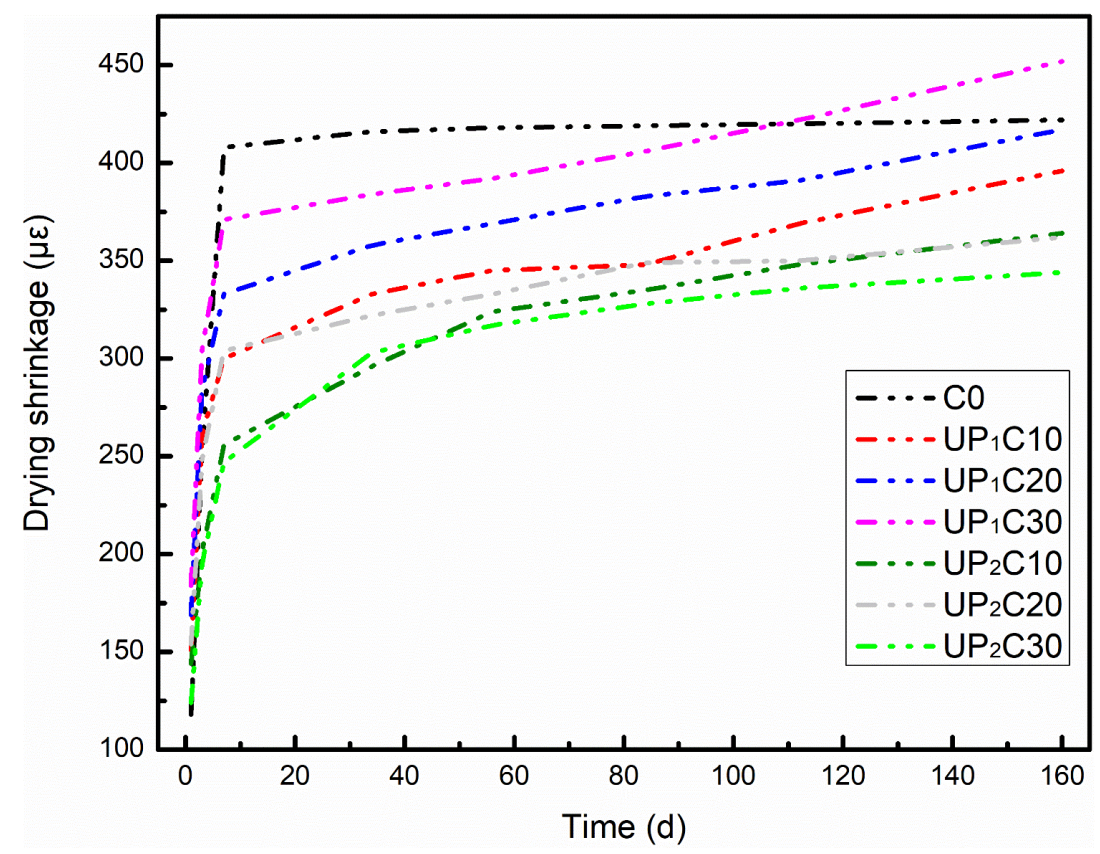

(a)

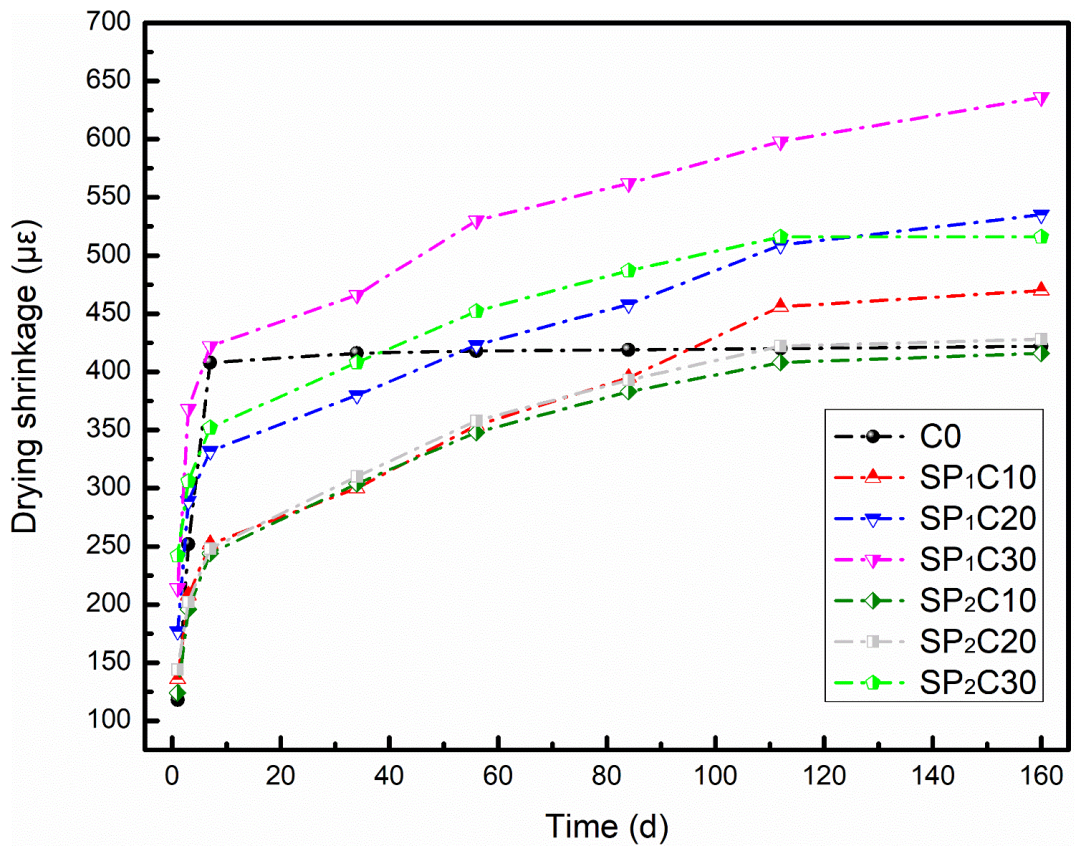

(b)

Figure 6. Influence of humid pumice on the persistent shrinkage deformation evolvement of the designed UHPC: (a) unsaturated pumice substitution; (b) saturated pumice substitution. 
In the 1 7 $\mathrm{d}$ age range, the shrinkage growth of the UHPC appending the humid pumice is still relatively fast, but its development rate begins to gradually slow down, and the total value of contraction within $7 \mathrm{~d}$ is lower than the control group. Compared with $\mathrm{C} 0$, the details of the total dry shrinkage rate during $7 \mathrm{~d}$ are that $\mathrm{UP}_{1} \mathrm{C} 10 \sim \mathrm{UP}_{1} \mathrm{C} 30$ shrinks by $26.5 \%, 18.4 \%$, and $9.1 \%$; $\mathrm{UP}_{2} \mathrm{C} 10 \sim \mathrm{UP}_{2} \mathrm{C} 30$ retracts by $37.3 \%, 25.5 \%$, and $39.5 \% ; \mathrm{SP}_{1} \mathrm{C} 10 \sim \mathrm{SP}_{1} \mathrm{C} 30$ shrinks by $38.2 \%, 18.6 \%$, and $-3.4 \%$; and $\mathrm{SP}_{2} \mathrm{C} 10 \sim \mathrm{SP}_{2} \mathrm{C} 30$ retracts by $40.2 \%, 39.2 \%$, and $13.7 \%$, respectively. It reveals that the intake of moisture at this stage remains the postponed effect of self-desiccation inside the matrix. The shrinkage of $\mathrm{SP}_{1} \mathrm{C} 30$ after $7 \mathrm{~d}$ has exceeded the value of $\mathrm{C} 0$, and it continues to grow in the later period at a high-speed. This can be attributed to the fact that the content of external water in the $\mathrm{SP}_{1} \mathrm{C} 30$ group is too large, the total $\mathrm{w} / \mathrm{b}$ of the mortar has reached 0.25 (beyond the scope of UHPC), which is disadvantageous to the microstructure development, and the porosity of concrete is then broadened, resulting in the deformation due to continuous moisture loss increases.

After seven days of hydration, the drying shrinkage of UHPC with dank pumice adjunction continues to develop. The total drying shrinkage of each group at a $160 \mathrm{~d}$ age $(\mathrm{C} 0=422 \mu \varepsilon)$ is $396 \mu \varepsilon$, $417 \mu \varepsilon$, and $452 \mu \varepsilon$ for $\mathrm{UP}_{1} \mathrm{C} 10 \sim \mathrm{UP}_{1} \mathrm{C} 30 ; 364 \mu \varepsilon, 362 \mu \varepsilon$, and $344 \mu \varepsilon$ for $\mathrm{UP}_{2} \mathrm{C} 10 \sim \mathrm{UP}_{2} \mathrm{C} 30 ; 470 \mu \varepsilon, 535$ $\mu \varepsilon$, and $636 \mu \varepsilon$ for $\mathrm{SP}_{1} \mathrm{C} 10 \sim \mathrm{SP}_{1} \mathrm{C} 30$; and $416 \mu \varepsilon, 428 \mu \varepsilon$, and $516 \mu \varepsilon$ for $\mathrm{SP}_{2} \mathrm{C} 10 \sim \mathrm{SP}_{2} \mathrm{C} 30$, respectively. Among them, in the $0-0.6 \mathrm{~mm}$ wet pumice particles replacement system, the extra water content more than $17.7 \mathrm{~g}$ will lead to an increase in the final shrinkage of UHPC. In that substitution group of the 0.6-1.25 mm pumice, the amount of water introduced will only need to be greater than $6.7 \mathrm{~g}$, and the total contraction will rise. The regularity that can be summarized is that the long-term shrinkage of UHPC combined with wet pumice is positively correlated with the amount of water introduced, and the larger particles contribute more to the final contraction deformation. This phenomenon can also be due to the higher water release efficiency of the larger size of pumice particles.

\subsection{Hydration Process Analysis}

The influence of extra water on the heat flow and total heat in the UHPC system within $72 \mathrm{~h}$ under several typical mix design conditions is collected in Figure 7 . The results indicate that the external moisture introduced by cellular mineral will not change the basic law of cement hydration, but merely has an impact on the hydration course, including exothermic peak location and total heat output. Moreover, it mainly affects the very early hydration, and has a limited influence on the stabilization period. The heat flow curves indicate that $\mathrm{C} 0, \mathrm{UP}_{1} \mathrm{C} 30, \mathrm{SP}_{2} \mathrm{C} 10$, and $\mathrm{SP}_{2} \mathrm{C} 30$ all have a distinct hydration exothermic peak, and the distribution range is $2 \sim 20 \mathrm{~h}$ after mixing, with good consistency. Despite the same tendency being presented, there are divergences between the exothermic peak values and time schedules in the violent stage, possessing the similar rules. In the period of acceleration, the exothermic peak of $\mathrm{C} 0, \mathrm{UP}_{1} \mathrm{C} 30, \mathrm{SP}_{2} \mathrm{C} 10$, and $\mathrm{SP}_{2} \mathrm{C} 30$ is $1.87 \mathrm{~mW} / \mathrm{g}, 2.15 \mathrm{~mW} / \mathrm{g}$, $1.89 \mathrm{~mW} / \mathrm{g}$, and $1.91 \mathrm{~mW} / \mathrm{g}$, respectively, and the corresponding occurrence time is $7.5 \mathrm{~h}, 8.8 \mathrm{~h}, 9.1 \mathrm{~h}$, and $9.7 \mathrm{~h}$. The height of the exothermic peak is positively correlated with the amount of extra water, which can persistently promote the progress during the hydration step [71]. The emergence time of that peak is related to the abundance of moisture in the vicinity of cement particles. Compared with the $0-0.6 \mathrm{~mm}$ pumice bead, the water-releasing rate of $0.6-1.25 \mathrm{~mm}$ is faster, which manifolds the gross of hydration products on the surface of cement granules within the effective range. The formation of the hydrated products film gravely inhibits the chemical reaction, leading to a modest lag in the time table for that crest [72]. The retarding effect of introducing water is an important reason for the significant decrease in the mechanical properties of UHPC mixed with wet pumice in one day. 


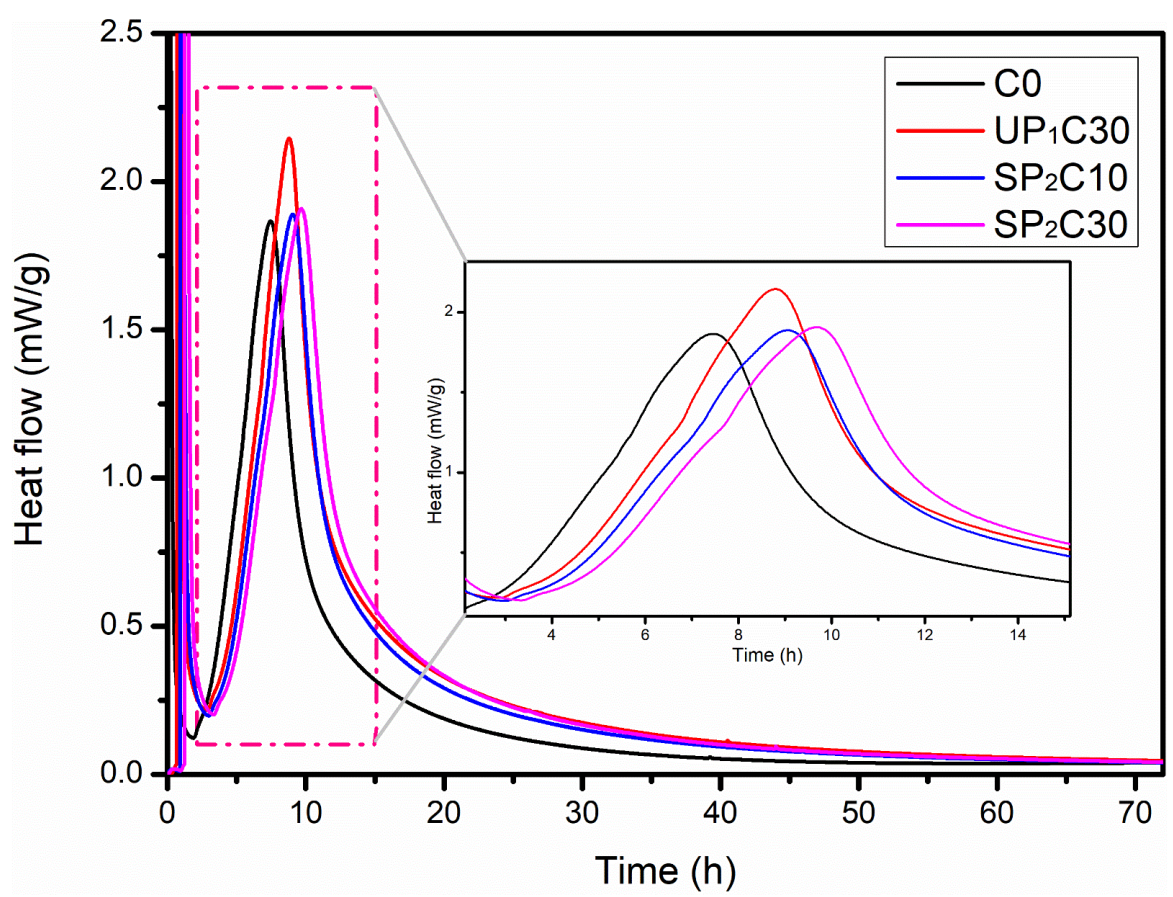

(a)

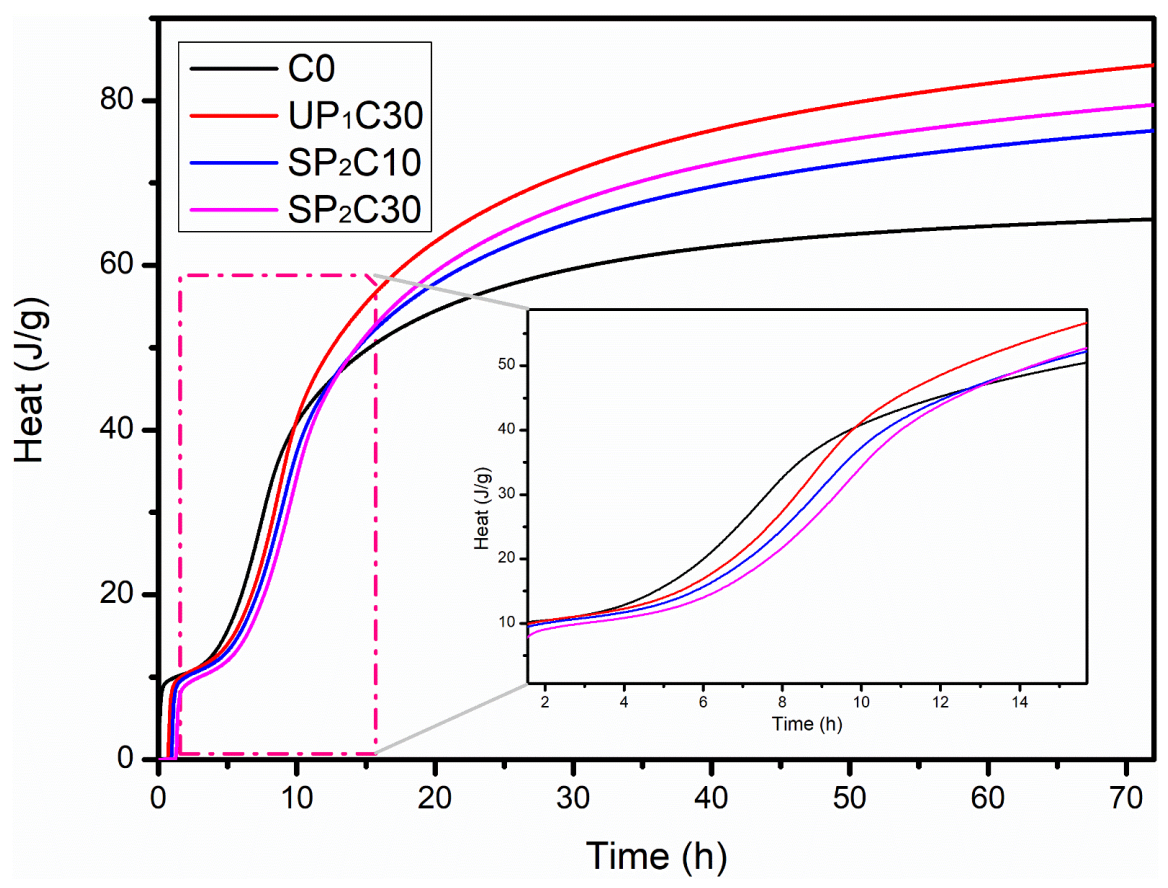

(b)

Figure 7. Heat evolution of UHPC system consisting of hydrated pumice within $72 \mathrm{~h}$ under several typical mix design conditions: (a) heat flow; (b) total heat.

The profiles of total heat reveal that the quantity of heat of $\mathrm{C} 0, \mathrm{UP}_{1} \mathrm{C} 30, \mathrm{SP}_{2} \mathrm{C} 10$, and $\mathrm{SP}_{2} \mathrm{C} 30$ within $72 \mathrm{~h}$ is $65.6 \mathrm{~J} / \mathrm{g}, 84.3 \mathrm{~J} / \mathrm{g}, 76.3 \mathrm{~J} / \mathrm{g}$, and $79.5 \mathrm{~J} / \mathrm{g}$, respectively. As can be gathered, the more added water there is, the higher heat the UHPC system produces. There is an environment with an extreme water shortage inside UHPC, and extra moisture will eventually participate in the reaction at different stages of hydration, improving the degree of hydration and the development of compensation strength. 


\subsection{XRD}

The XRD patterns of several representative UHPC samples at $7 \mathrm{~d}$ and $28 \mathrm{~d}$ are given in Figure 8 . The characterizations of hydration products elaborate that the main phases of different ages in UHPC are $\mathrm{Ca}(\mathrm{OH})_{2}, \mathrm{Aft}$, and $\mathrm{CaCO}_{3}$, and the introduction of water-absorbing pumice does not produce byproducts. Besides, there are obvious $\mathrm{C}_{2} \mathrm{~S}, \mathrm{C}_{3} \mathrm{~S}$, and $\mathrm{C}_{4} \mathrm{AF}$ characteristic peaks in each group due to unhydrated cement particles in the UHPC hardened paste.

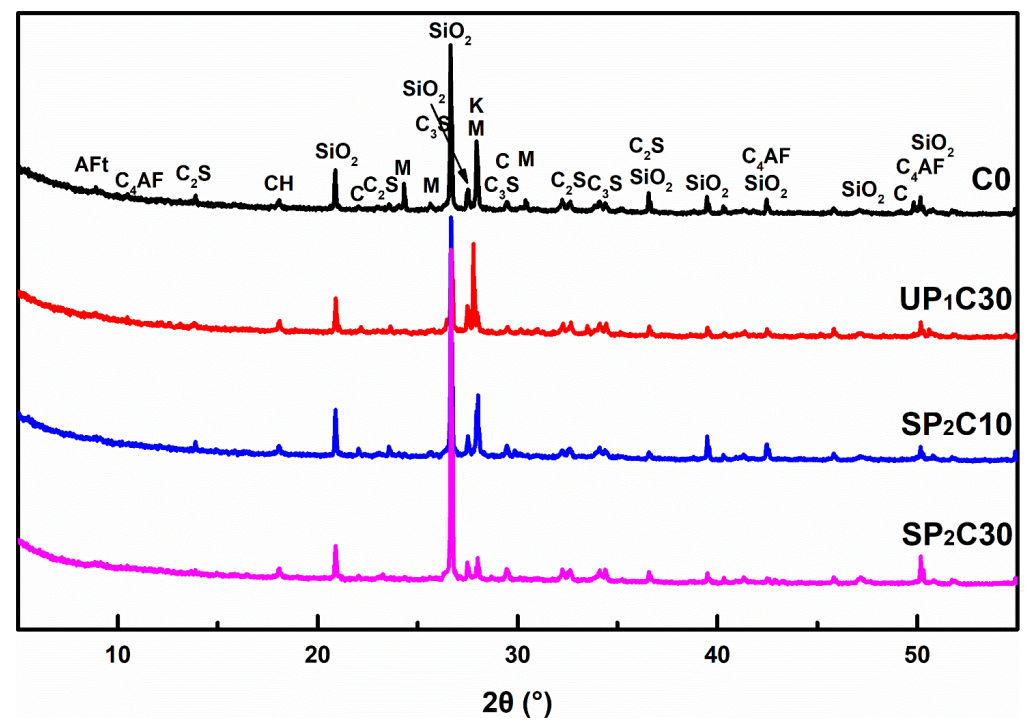

(a)

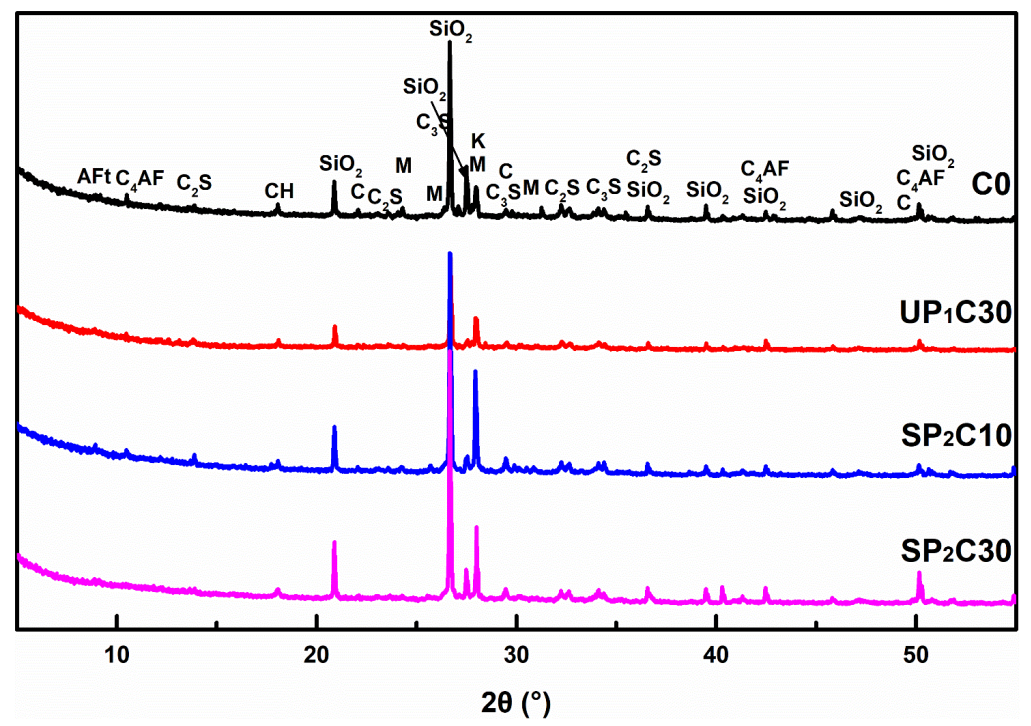

(b)

CH: $\mathrm{Ca}(\mathrm{OH}) 2$, (PDF (ICDD) 04-0733)

M: Margarite, (PDF (ICDD) 18-0276)

$\mathrm{K}: \mathrm{Al}_{2} \mathrm{SiO}_{5}$, (PDF (ICDD) 11-0046)

C: Calcite. (PDF (ICDD) 51-1524)

Figure 8. XRD pattern of UHPC hardened paste formed with pre-humid pumice at $7 \mathrm{~d}$ and $28 \mathrm{~d}$ age: (a) $7 \mathrm{~d}$ age; (b) $28 \mathrm{~d}$ age. 
To have a better understanding of the hydration mechanism of wet pumice in UHPC, the $\mathrm{Ca}(\mathrm{OH})_{2}$ content in the $7 \mathrm{~d}$ and $28 \mathrm{~d}$ samples of the $\mathrm{SP}_{2} \mathrm{C} 30$ group is qualitatively analyzed and calculated as shown in Figure 9. A specific $\mathrm{SiO}_{2}$ peak is chosen as the control object $(2 \theta=20.89)$ to furthest eliminate the fluctuation of test errors, and the ratio of $\mathrm{Ca}(\mathrm{OH})_{2}$ to the corresponding peak area of that $\mathrm{SiO}_{2}$ in diffraction patterns of the $7 \mathrm{~d}$ and $28 \mathrm{~d}$ concrete specimens is computed. Evaluation results reveal that the $\mathrm{Ca}(\mathrm{OH})_{2}$ consumption rate in $\mathrm{C} 0$ is $17.6 \%$ in the range of $7-28$ days, while that of $\mathrm{SP}_{2} \mathrm{C} 30$ is $23.1 \%$. It proves that the external moisture carried by the IC agent will stimulate the second hydration of pozzolanic active admixture in the system earlier, which is consistent with the results of hydration heat analysis. The introduction of external water to promote the hydration process of the UHPC cementitious system (Cement, FA, and SF) is an important source of compensation strength development.

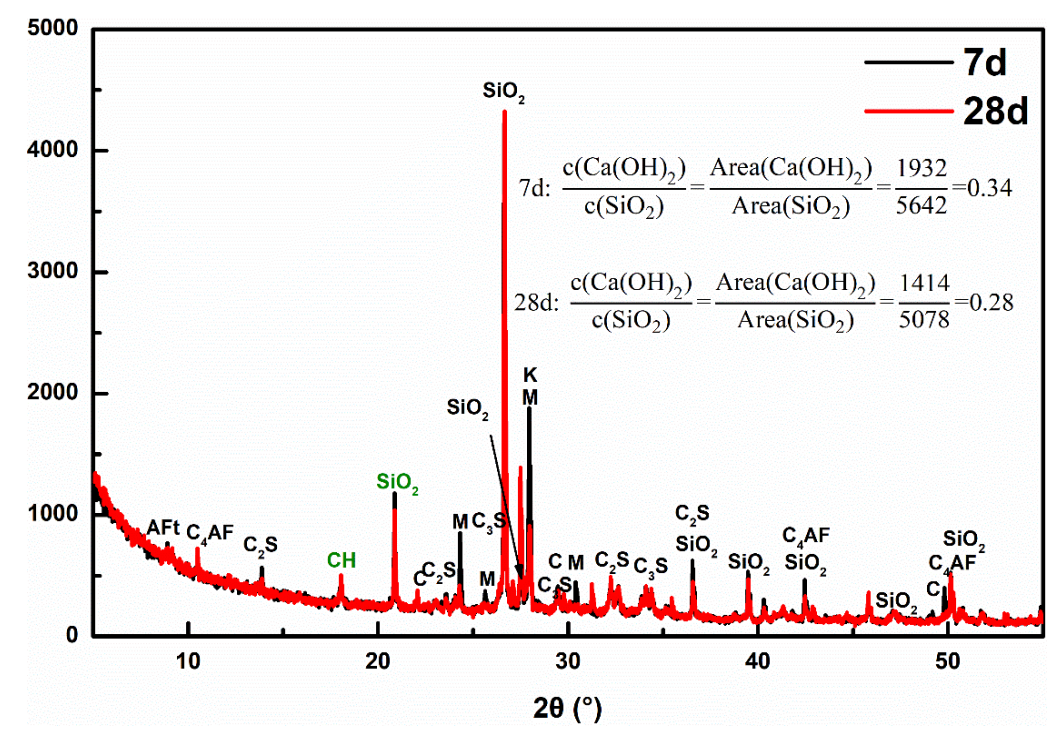

(a) $\mathrm{CO}$

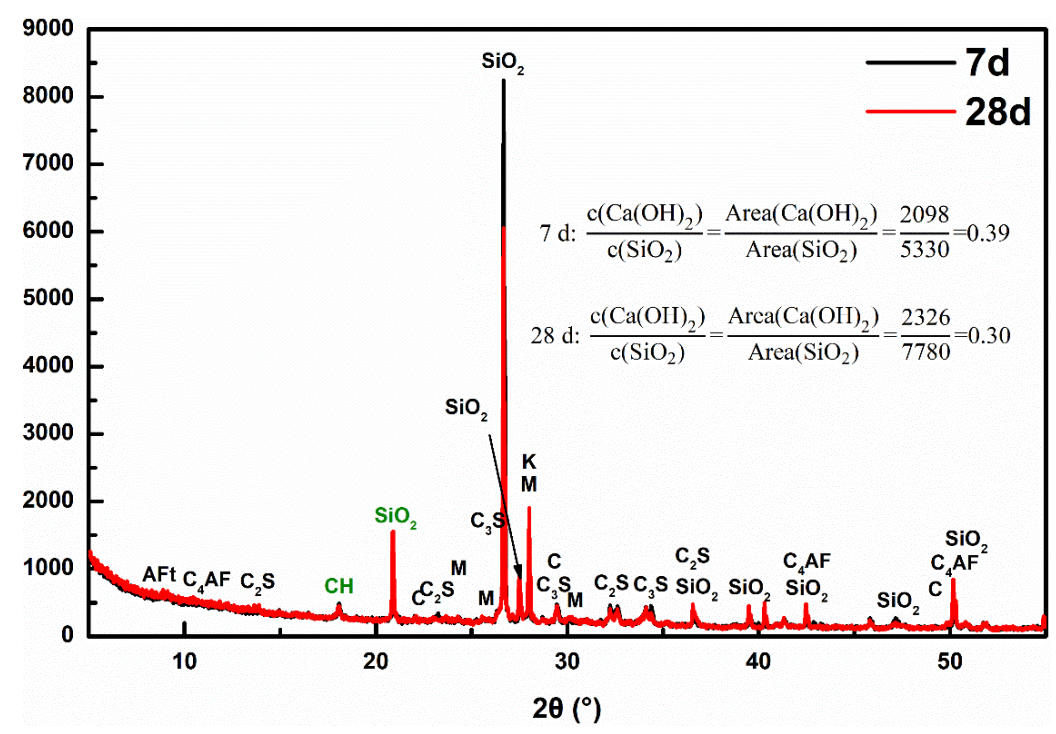

(b) $\mathrm{SP}_{2} \mathrm{C} 30$

Figure 9. XRD qualitative analysis the content of $\mathrm{Ca}(\mathrm{OH})_{2}$ in specimens of $\mathrm{C} 0$ and $\mathrm{SP}_{2} \mathrm{C} 30$ groups for $7 \mathrm{~d}$ and $28 \mathrm{~d}$ curing age: (a) $\mathrm{C} 0$; (b) $\mathrm{SP}_{2} \mathrm{C} 30$. 


\subsection{DTG}

Thermogravimetric analysis is also performed on the samples mentioned above, and the DTG curves for the tested specimen at $7 \mathrm{~d}$ and $28 \mathrm{~d}$ are exhibited in Figure 10; incidentally, the yield of $\mathrm{Ca}(\mathrm{OH})_{2}$ based on calculation is presented in Table 4. According to Figure 10a, the hydration of the cementitious system at $7 \mathrm{~d}$ is accelerated by incorporating wet pumice. The weight loss curve of each group at different stages is comparatively analyzed, and sums up that the UHPC designed with the IC mechanism compared to the control group has the following details: (1) The mass loss of C-S-H and $\mathrm{AFt}$ in the composite mortar within the range of $100 \sim 200{ }^{\circ} \mathrm{C}$ while the influence of adsorbed water has been excluded becomes larger, indicating that the content of hydration products in the gelling system increases; (2) although the total amount of $\mathrm{CaCO}_{3}$ formed by carbonation of $\mathrm{Ca}(\mathrm{OH})_{2}$ is significantly increased, the remaining quality of $\mathrm{Ca}(\mathrm{OH})_{2}$ is still large, testifying that the production of $\mathrm{Ca}(\mathrm{OH})_{2}$ is also palpably raised, which is sensitive for the large beads; (3) the location of the main decomposition peak of $\mathrm{CaCO}_{3}$ manifests some right shifts, which means that the carbonation time is prolonged, and the incipient gelation framework develops slowly. This phenomenon has been corroborated and supported by the widespread suppression of its $1 \mathrm{~d}$ strength development.

Table 4. Generation of $\mathrm{Ca}(\mathrm{OH})_{2}$ for corresponding representative groups based on calculation by DTG curves (\%).

\begin{tabular}{ccccc}
\hline Group & $\mathbf{C 0}$ & $\mathbf{U P}_{\mathbf{1}} \mathbf{C} 30$ & $\mathbf{S P}_{\mathbf{2}} \mathbf{C 1 0}$ & $\mathbf{S P}_{\mathbf{2}} \mathbf{C} 30$ \\
\hline $7 \mathrm{~d}$ & 0.387 & 0.517 & 0.506 & 0.550 \\
$28 \mathrm{~d}$ & 0.420 & 0.348 & 0.385 & 0.423 \\
\hline
\end{tabular}

The results shown in Figure 10a,b have a good overall consistency, demonstrating that the effect of pumice containing water on the promotion of hydration of the UHPC system is a continuous process, and the reasoning agrees with the deduction of XRD analysis. After the introduction of the IC pumice, the content of $\mathrm{Ca}(\mathrm{OH})_{2}$ is notably lowered at a $28 \mathrm{~d}$ age compared to the $7 \mathrm{~d}$ age samples; contrarily, that of $\mathrm{Ca}(\mathrm{OH})_{2}$ is increased in the control group of UHPC. This is additional evidence that the extra water will promote the secondary hydration of SF and FA in the composite system, which consumes part of $\mathrm{Ca}(\mathrm{OH})_{2}$.

\subsection{ESEM-EDS}

$\mathrm{C}-\mathrm{S}-\mathrm{H}$ gel is the most important hydration product and cementing component in concrete. It is generally accepted that the $\mathrm{C}-\mathrm{S}-\mathrm{H}$ in the hydration products of cement-based materials is divided into two types: C-S-H (I) and C-S-H (II). Among them, Ca/Si of C-S-H (I) is $0.6-1.5$, and Ca/Si of $\mathrm{C}-\mathrm{S}-\mathrm{H}$ (II) is about $2.0[73,74]$. The $\mathrm{Ca} / \mathrm{Si}$ of $\mathrm{C}-\mathrm{S}-\mathrm{H}$ in the hydration products of the 28-day-old UHPC specimen pieces is evaluated by ESEM-EDS, as exhibited in Figure 11. The results reveal that the introduction of humid fine aggregates will lead to a sharp drop in the average $\mathrm{Ca} / \mathrm{Si}$ of $\mathrm{C}-\mathrm{S}-\mathrm{H}$ in the neighboring mortar. This means that the IC moisture can not only promote the hydration process of the UHPC gelling system, but also make it easier for the reaction to form C-S-H (I), which bears a lower degree of polymerization and crystallinity. The mechanism that causes this phenomenon comes from two aspects: firstly, water introduced by wet pumice will increase the actual $\mathrm{w} / \mathrm{b}$ of the mortar within its effective range, resulting in a change in the regional hydration products, especially the $\mathrm{C}-\mathrm{S}-\mathrm{H}$ structure $[75,76]$. Secondly, the $\mathrm{Ca} / \mathrm{Si}$ in C-S-H is proportional to the content of $\mathrm{Ca}(\mathrm{OH})_{2}$ in hardened paste [77], as mentioned in the previous section, and the IC moisture can activate the pozzolanic reaction of active admixtures more and consume $\mathrm{Ca}(\mathrm{OH})_{2}$, resulting in aCa/Si decrease in $\mathrm{C}-\mathrm{S}-\mathrm{H}$. The mutation of the C-S-H structure has a non-negligible influence on the UHPC strength development and the extremely late drying shrinkage deformation using the IC mechanism, while C-S-H loses interlayer water and C-S-H gel particles produce irreversible permanent rearrangement $[78,79]$. 


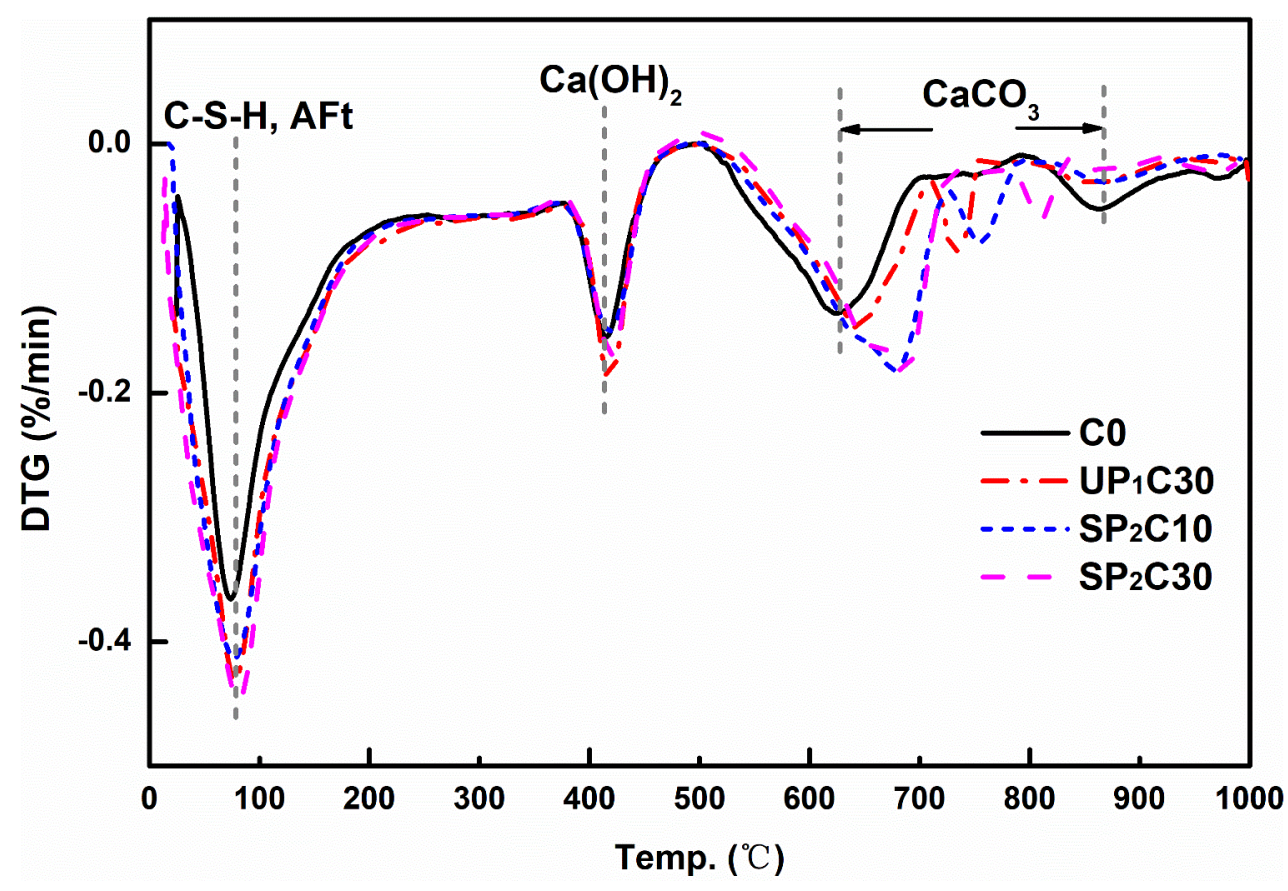

(a)

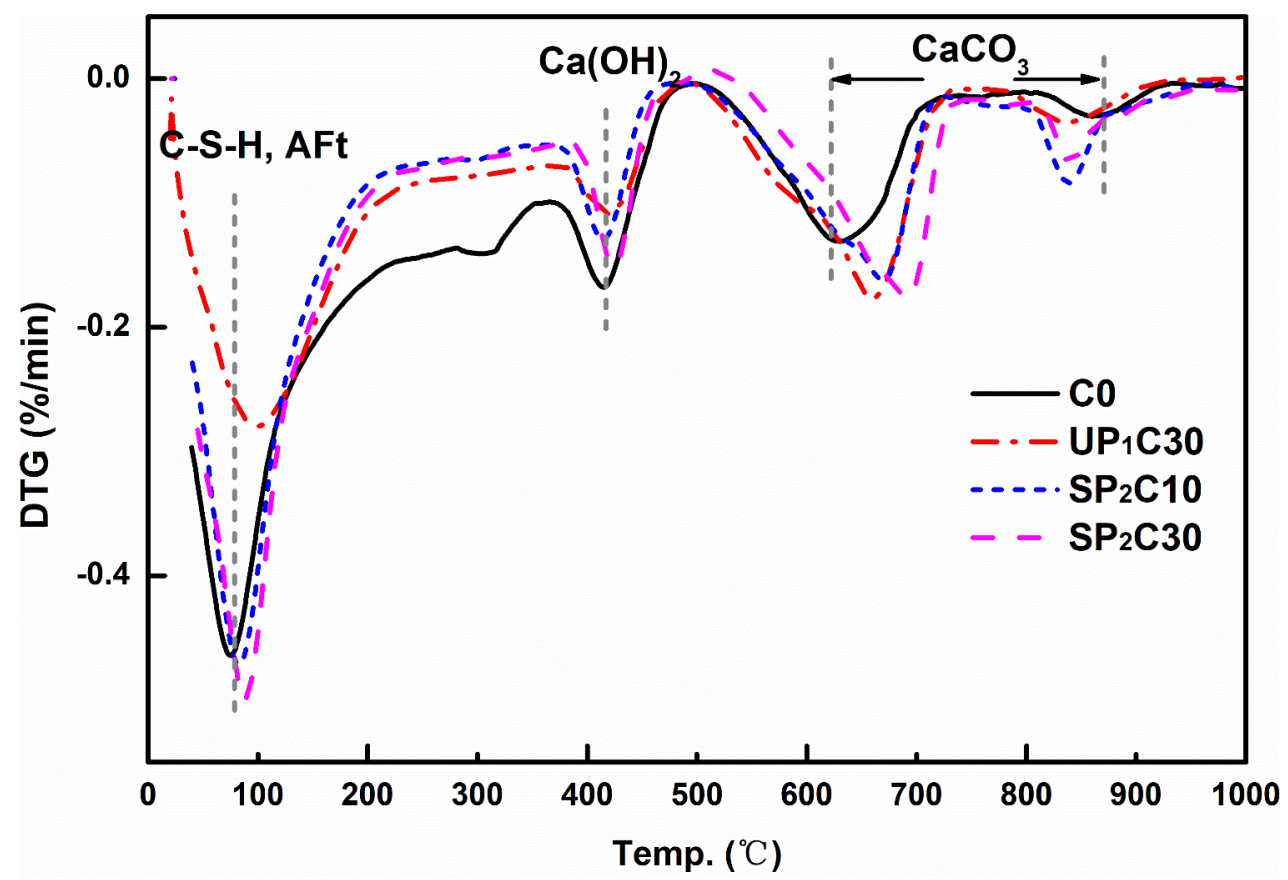

(b)

Figure 10. Effect of wet pumice on the thermal decomposition characteristics of several typical UHPC recipes after $7 \mathrm{~d}$ and $28 \mathrm{~d}$ : (a) $7 \mathrm{~d}$; (b) $28 \mathrm{~d}$. 


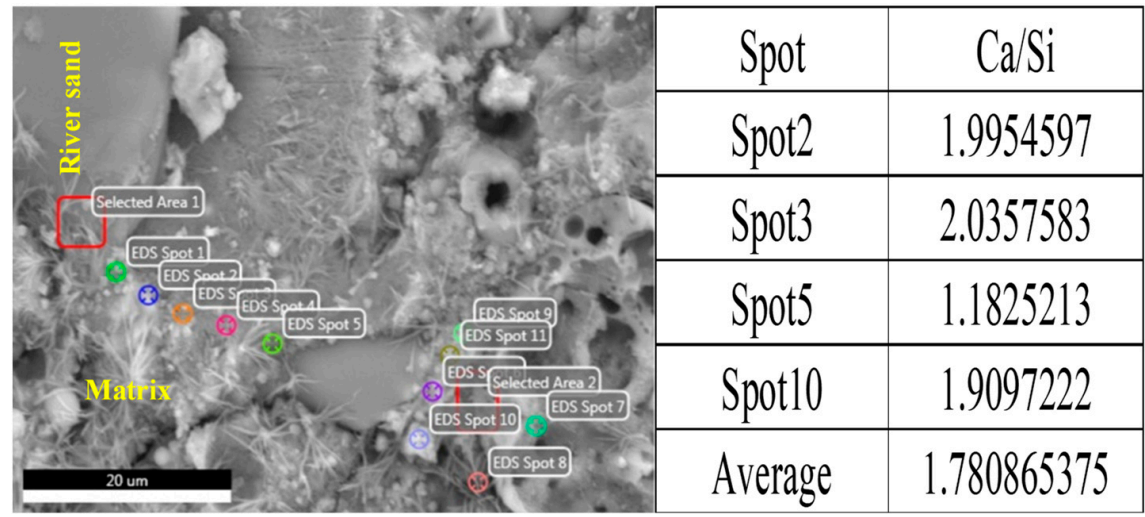

(a) $\mathrm{C} 0$

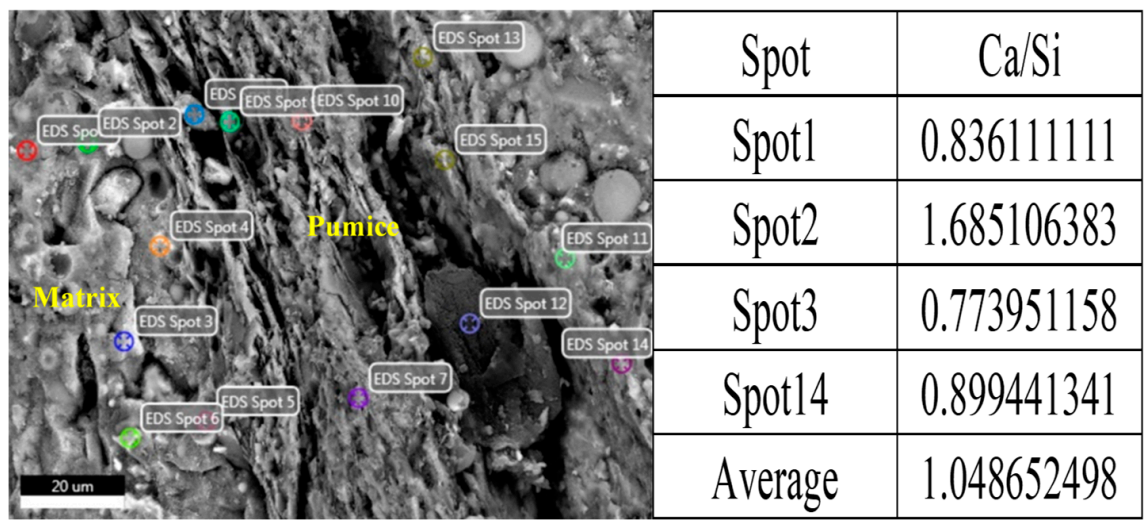

(b) $\mathrm{SP}_{2} \mathrm{C} 10$

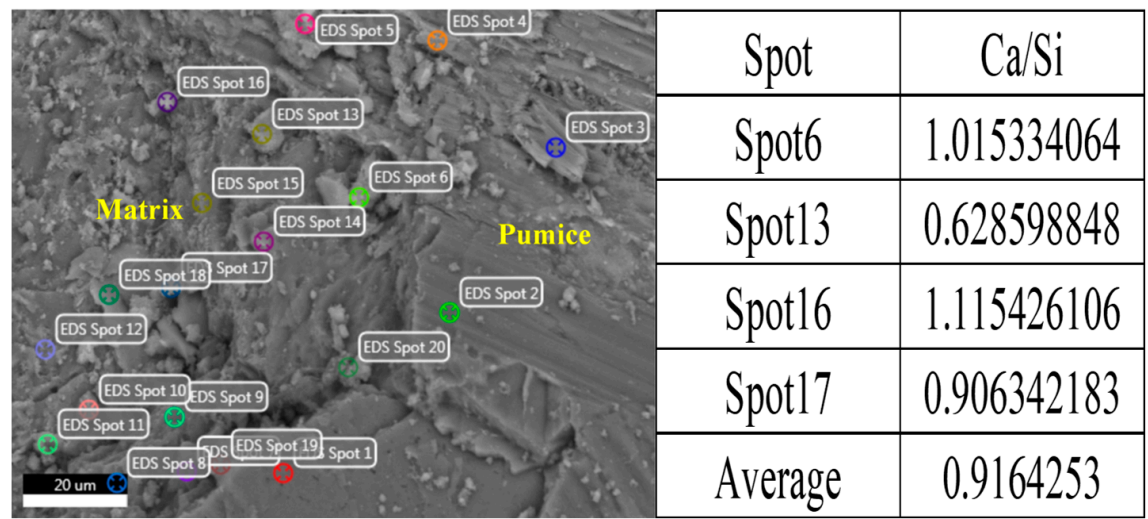

(c) $\mathrm{SP}_{2} \mathrm{C} 30$

Figure 11. EDS elemental content analysis of the matrix nearby river sand and wet pumice in $\mathrm{C} 0$, $\mathrm{SP}_{2} \mathrm{C} 10$, and $\mathrm{SP}_{2} \mathrm{C} 30$ samples mentioned above after 28 d curing: (a) $\mathrm{C} 0$; (b) $\mathrm{SP}_{2} \mathrm{C} 10$; (c) $\mathrm{SP}_{2} \mathrm{C} 30$.

\section{Conclusions}

In this paper, the effects of water-absorbing pumice on the persistent drying shrinkage and hydration characteristics of UHPC are investigated. Combined with comprehensive characterization analysis, the conclusions are summarized as follows:

(1) The flowability of UHPC fresh paste is related to the water absorption and release behavior of wet pumice during mixing. For the $0-0.6 \mathrm{~mm}$ humid pumice substitution system, the injection action 
plays a dominant role when the water content exceeds $17.7 \mathrm{~g}$. For that of the $0.6-1.25 \mathrm{~mm}$ replacement system, the volume quantities need more than $20 \%$ to ensure that the injection action has priority.

(2) The introduction of IC water will result in an average decrease of $8.8 \%$ in the compressive strength of UHPC after $28 \mathrm{~d}$ curing; meanwhile, the flexural strength will be increased.

(3) Incorporation of impregnated pumice will inhibit the early drying shrinkage deformation behavior of UHPC, but the specimen will continue to contract during the later stage. There is a satisfied rule that the final total shrinkage is proportional to the content of extra water for the unified displacement system, while the larger size of LWA IC granules has greater potential adverse effects on the persistent dry contraction of concrete.

(4) The optimum recipe is $0.6-1.25 \mathrm{~mm}$ pumice particles in a saturated water absorption state replacing $10 \%$ river sands with the same particle size by volume fraction $\left(\mathrm{SP}_{2} \mathrm{C} 10\right)$. Its compressive strength increases slightly and the flexural strength increases by $41.3 \%$ at $28 \mathrm{~d}$. Meanwhile, the total shrinkage is effectively reduced within $160 \mathrm{~d}$.

(5) The additional water has a retarding effect on mortar, which will delay the peak of the hydration exotherm, but raise the rate of heat release during the accelerated period of hydration and the total exothermic energy of the system.

(6) The introduction of water into pumice will promote the hydration process of the UHPC cementitious system. This effect is a continuous proceeding, including early cement hydration and secondary hydration of the reactive powders.

(7) The wet pumice will make the hydration reaction of the paste nearby more likely to generate C-S-H (I) with poor crystallinity, resulting in changes in the composition and structure of hydration products in its effective area.

Author Contributions: Conceptualization, R.Y. and Z.S.; Methodology, K.L. and R.Y.; Formal Analysis, K.L. and X.L. (Xiaosheng Li); Investigation, K.L., W.H. and S.Y.; Writing-Original Draft Preparation, K.L. and X.L. (Xuan Ling); Writing-Review \& Editing, K.L. and R.Y.; Visualization, R.Y. and S.W.; Funding Acquisition, R.Y. and Z.S.

Funding: This research was funded by the National Nature Science Foundation Project of China (51608409 and 51679179); Major science and technology project in Zhongshan city, Guangdong province (2017A1021); Yang Fan plan of Guangdong Province (201312C12); Science and Technology Program of Guangdong Province in 2016 (2016A090924002); Science and Technology Program of Guangdong Province in 2017 (2017B090907009); Late-model Research Institute Development Program of Zhongshan in 2016: Subsidy for Major Research Platform Construction (2016F2FC0008); and open research project of Advanced Engineering Technology Research Institute of Wuhan University of technology in Zhongshan city (WUT201802).

Conflicts of Interest: The authors declare no conflict of interest.

\section{References}

1. Richard, P.; Cheyrezy, M. Composition of reactive powder concretes. Cem. Concr. Res. 1995, 25, $1501-1511$. [CrossRef]

2. Habel, K.; Viviani, M.; Denarié, E.; Brühwiler, E. Development of the mechanical properties of an Ultra-High Performance Fiber Reinforced Concrete (UHPFRC). Cem. Concr. Res. 2006, 36, 1362-1370. [CrossRef]

3. Shi, C.; Wu, Z.; Xiao, J.; Wang, D.; Huang, Z.; Fang, Z. A review on ultra high performance concrete: Part I. Raw materials and mixture design. Constr. Build. Mater. 2015, 101, 741-751. [CrossRef]

4. Wang, D.; Shi, C.; Wu, Z.; Xiao, J.; Huang, Z.; Fang, Z. A review on ultra high performance concrete: Part II. Hydration, microstructure and properties. Constr. Build. Mater. 2015, 96, 368-377. [CrossRef]

5. Rahman, S.; Molyneaux, T.; Patnaikuni, I. Ultra high performance concrete: Recent applications and research. Aust. J. Civ. Eng. 2005, 2, 13-20. [CrossRef]

6. Yu, R. Development of Sustainable Protective Ultra-High Performance Fibre Reinforced Concrete (UHPFRC): Design, assessment and modeling. Ph.D. Thesis, Eindhoven University of Technology, Eindhoven, The Netherlands, 2015.

7. Bărbos, G.-A. Long-term Behavior of Ultra-High Performance Concrete (UHPC) Bended Beams. Procedia Technol. 2016, 22, 203-210.

8. Yoo, D.Y.; Yoon, Y.S. A Review on Structural Behavior, Design, and Application of Ultra-High-Performance Fiber-Reinforced Concrete. Int. J. Concr. Struct. Mater. 2016, 10, 125-142. [CrossRef] 
9. Zhou, M.; Lu, W.; Song, J.W.; Lee, G.C. Application of Ultra-High Performance Concrete in bridge engineering. Constr. Build. Mater. 2018, 186, 1256-1267. [CrossRef]

10. Ren, L.; Fang, Z.; Wang, K. Design and behavior of super-long span cable-stayed bridge with CFRP cables and UHPC members. Compos. Part B Eng. 2018. [CrossRef]

11. Azmee, N.M.; Shafiq, N. Ultra-high performance concrete: From fundamental to applications. Case Stud. Constr. Mater. 2018. [CrossRef]

12. Lura, P.; Jensen, O.M.; van Breugel, K. Autogenous shrinkage in high-performance cement paste: An evaluation of basic mechanisms. Cem. Concr. Res. 2003, 33, 223-232. [CrossRef]

13. Garas, V.Y.; Kahn, L.F.; Kurtis, K.E. Short-term tensile creep and shrinkage of ultra-high performance concrete. Cem. Concr. Compos. 2009, 31, 147-152. [CrossRef]

14. Xie, T.; Fang, C.; Ali, M.S.M.; Visintin, P. Characterizations of autogenous and drying shrinkage of ultra-high performance concrete (UHPC): An experimental study. Cem. Concr. Compos. 2018, 91, 156-173. [CrossRef]

15. Justs, J.; Wyrzykowski, M.; Bajare, D.; Lura, P. Internal curing by superabsorbent polymers in ultra-high performance concrete. Cem. Concr. Res. 2015, 76, 82-90. [CrossRef]

16. Sensale, G.R.D.; Goncalves, A.F. Effects of Fine LWA and SAP as Internal Water Curing Agents. Int. J. Concr. Struct. Mater. 2014, 8, 229-238. [CrossRef]

17. Van, V.T.A.; Rößler, C.; Bui, D.D.; Ludwig, H.-M. Rice husk ash as both pozzolanic admixture and internal curing agent in ultra-high performance concrete. Cem. Concr. Compos. 2014, 53, 270-278. [CrossRef]

18. Liu, J.; Ou, Z.; Mo, J.; Chen, Y.; Guo, T.; Deng, W. Effectiveness of Saturated Coral Aggregate and Shrinkage Reducing Admixture on the Autogenous Shrinkage of Ultrahigh Performance Concrete. Adv. Mater. Sci. Eng. 2017, 2017, 1-11. [CrossRef]

19. Meng, W.; Khayat, K. Effects of saturated lightweight sand content on key characteristics of ultra-high-performance concrete. Cem. Concr. Res. 2017, 101, 46-54. [CrossRef]

20. Sun, W.; Chen, H.; Luo, X.; Qian, H. The effect of hybrid fibers and expansive agent on the shrinkage and permeability of high-performance concrete. Cem. Concr. Res. 2001, 31, 595-601. [CrossRef]

21. Corinaldesi, V.; Nardinocchi, A.; Donnini, J. The influence of expansive agent on the performance of fibre reinforced cement-based composites. Constr. Build. Mater. 2015, 91, 171-179. [CrossRef]

22. Soliman, A.M.; Nehdi, M.L. Effects of shrinkage reducing admixture and wollastonite microfiber on early-age behavior of ultra-high performance concrete. Cem. Concr. Compos. 2014, 46, 81-89. [CrossRef]

23. Yoo, D.Y.; Banthia, N.; Yoon, Y.S. Effectiveness of shrinkage-reducing admixture in reducing autogenous shrinkage stress of ultra-high-performance fiber-reinforced concrete. Cem. Concr. Compos. 2015, 64, 27-36. [CrossRef]

24. Ghafari, E.; Ghahari, S.A.; Costa, H.; Júlio, E.; Portugal, A.; Durães, L. Effect of supplementary cementitious materials on autogenous shrinkage of ultra-high performance concrete. Constr. Build. Mater. 2016, 127, $43-48$. [CrossRef]

25. Li, W.; Huang, Z.; Hu, G.; Duan, W.; Shah, S.P. Early-age shrinkage development of ultra-high-performance concrete under heat curing treatment. Constr. Build. Mater. 2017, 131, 767-774. [CrossRef]

26. Shen, P.; Lu, L.; He, Y.; Rao, M.; Fu, Z.; Wang, F.; Hu, S. Experimental investigation on the autogenous shrinkage of steam cured ultra-high performance concrete. Constr. Build. Mater. 2018, 162, 512-522. [CrossRef]

27. Rajabipour, F.; Sant, G.; Weiss, J. Interactions between shrinkage reducing admixtures (SRA) and cement paste's pore solution. Cem. Concr. Res. 2008, 38, 606-615. [CrossRef]

28. Soliman, A.M.; Nehdi, M.L. Effect of partially hydrated cementitious materials and superabsorbent polymer on early-age shrinkage of UHPC. Constr. Build. Mater. 2013, 41, 270-275. [CrossRef]

29. Kang, S.H.; Hong, S.G.; Moon, J. Shrinkage characteristics of heat-treated ultra-high performance concrete and its mitigation using superabsorbent polymer based internal curing method. Cem. Concr. Compos. 2018, 89, 130-138. [CrossRef]

30. Philleo, R. Concrete Science and Reality. In Materials Science of Concrete II; American Ceramic Society: Westerville, OH, USA, 1991; pp. 1-8.

31. Bentz, D.P.; Snyder, K.A. Protected paste volume in concrete: Extension to internal curing using saturated lightweight fine aggregate. Cem. Concr. Res. 1999, 29, 1863-1867. [CrossRef]

32. Bentz, D.P.; Lura, P.; Roberts, J.W. Mixture Proportioning for Internal Curing. Concr. Int. 2005, 27, 35-40. 
33. Bentz, D.P. A review of early-age properties of cement-based materials. Cem. Concr. Res. 2008, 38, $196-204$. [CrossRef]

34. Bentur, A.; Igarashi, S.I.; Kovler, K. Prevention of autogenous shrinkage in high-strength concrete by internal curing using wet lightweight aggregates. Cem. Concr. Res. 2001, 31, 1587-1591. [CrossRef]

35. Akcay, B.; Tasdemir, M.A. Optimisation of using lightweight aggregates in mitigating autogenous deformation of concrete. Constr. Build. Mater. 2009, 23, 353-363. [CrossRef]

36. Akcay, B.; Tasdemir, M.A. Effects of distribution of lightweight aggregates on internal curing of concrete. Cem. Conc. Compos. 2010, 32, 611-616. [CrossRef]

37. Henkensiefken, R.; Nantung, T.; Weiss, J. Internal Curing-From the Laboratory to Implementation. In Proceedings of the International Bridge Conference on Lightweight Aggregate Concrete Bridges Workshop, Pittsburgh, PA, USA, 14-17 June 2009.

38. Henkensiefken, R.; Bentz, D.; Nantung, T.; Weiss, J. Volume change and cracking in internally cured mixtures made with saturated lightweight aggregate under sealed and unsealed conditions. Cem. Concr. Compos. 2009, 31, 427-437. [CrossRef]

39. Lura, P.; Wyrzykowski, M.; Tang, C.; Lehmann, E. Internal curing with lightweight aggregate produced from biomass-derived waste. Cem. Concr. Res. 2014, 59, 24-33. [CrossRef]

40. Zhutovsky, S.; Kovler, K.; Bentur, A. Efficiency of lightweight aggregates for internal curing of high strength concrete to eliminate autogenous shrinkage. Mater. Struct. 2002, 35, 97-101. [CrossRef]

41. Zhutovsky, S.; Kovler, K.; Bentur, A. Influence of cement paste matrix properties on the autogenous curing of high-performance concrete. Cem. Concr. Compos. 2004, 26, 499-507. [CrossRef]

42. Zhutovsky, S.; Kovler, K. Effect of internal curing on durability-related properties of high performance concrete. Cem. Concr. Res. 2012, 42, 20-26. [CrossRef]

43. Jensen, O.M.; Hansen, P.F. Water-entrained cement-based materials-I. Principles and theoretical background. Cem. Concr. Res. 2001, 31, 647-654. [CrossRef]

44. Craeye, B.; Schutter, G.D. Experimental evaluation of mitigation of autogenous shrinkage by means of a vertical dilatometer for concrete. In Proceedings of the Conference on Volume Changes of Hardening Concrete: Testing and Mitigation, Lyngby, Denmark, 20-23 August 2006; RILEM Publications SARL: UGent, Belgium, 2006; pp. 21-30.

45. Cusson, D.; Hoogeveen, T. Internal curing of high-performance concrete with pre-soaked fine lightweight aggregate for prevention of autogenous shrinkage cracking. Cem. Concr. Res. 2008, 38, 757-765. [CrossRef]

46. Paul, A.; Lopez, M. Assessing Lightweight Aggregate Efficiency for Maximizing Internal Curing Performance. ACI Mater. J. 2011, 108, 385-393.

47. Castro, J.; Keiser, L.; Golias, M.; Weiss, J. Absorption and desorption properties of fine lightweight aggregate for application to internally cured concrete mixtures. Cem. Concr. Compos. 2011, 33, 1001-1008. [CrossRef]

48. Internal Curing of Concrete, State-of-the-Art Report of RILEM Technical Committee 196-ICC (RILEM TC 196-ICC); RILEM Publications S.A.R.L.: Bagneux, France, 2007.

49. Suzuki, M.; Meddah, M.S.; Sato, R.; Kawabata, T. Long-term shrinkage and stress in ultra high strength concrete using porous ceramic waste for internal curing. In Proceedings of the International RILEM Conference on Use of Superabsorbent Polymers and Other New Additives in Concrete, Technical University of Denmark, Lyngby, Denmark, 15-18 August 2010.

50. Wang, X.P.; Yu, R.; Shui, Z.; Songa, Q.; Zhang, Z. Mix design and characteristics evaluation of an eco-friendly Ultra-High Performance Concrete incorporating recycled coral based materials. J. Clean. Prod. 2017, 165, 70-80. [CrossRef]

51. Klug, C.; Cashman, K.; Bacon, C. Structure and physical characteristics of pumice from the climactic eruption of Mount Mazama (Crater Lake), Oregon. Bull. Volcanol. 2002, 64, 486-501.

52. Hossain, A.; Khandaker, M. Properties of volcanic pumice based cement and lightweight concrete. Cem. Concr. Res. 2004, 34, 283-291. [CrossRef]

53. Binici, H. Effect of crushed ceramic and basaltic pumice as fine aggregates on concrete mortars properties. Constr. Build. Mater. 2007, 21, 1191-1197. [CrossRef]

54. Hossain, K.M.A.; Ahmed, S.; Lachemi, M. Lightweight concrete incorporating pumice based blended cement and aggregate: Mechanical and durability characteristics. Constr. Build. Mater. 2011, 25, 1186-1195. [CrossRef] 
55. Castro, J.; Weiss, J.; Henkensiefken, R.; Nantung, T.; Bentz, D.P. LWA Absorption and Desorption: The Influence on the Microstructure and Transport Properties of Internally Cured Mortars. In Proceedings of the International Conference on Concrete Under Severe Conditions: Environment \& Loading, Merida, Mexico, 7-9 June 2010; Taylor \& Francis Group: London, UK, 2010; pp. 1543-1550.

56. ASTM C09, C1761: Standard Specification for Lightweight Aggregate for Internal Curing of Concrete; ASTM: West Conshohocken, PA, USA, 2013.

57. Hüsken, G. A Multifunctional Design Approach for Sustainable Concrete with Application to Concrete Mass Products. Ph.D. Thesis, Eindhoven University of Technology, Eindhoven, The Netherlands, 2010.

58. Yu, R.; Spiesz, P.; Brouwers, H.J.H. Mix design and properties assessment of Ultra- High Performance Fibre Reinforced Concrete (UHPFRC). Cem. Concr. Res. 2014, 56, 29-39. [CrossRef]

59. GB/T 2419-2005. PRC National Standard: Test Method for Fluidity of Cement Mortar; Standards Press of China: Beijing, China, 2005. (In Chinese)

60. GB/T 17671-1999. PRC National Standard: Method of Testing Cements-Determination of Strength; Standards Press of China: Beijing, China, 1999. (In Chinese)

61. JC/T 603-2004. PRC Building Materials Industry Standard: Standard Test Method for Drying Shrinkage of Mortar; Standards Press of China: Beijing, China, 2004. (In Chinese)

62. Aïtcin, P.C. High Performance Concrete; CRC Press: Boca Raton, FL, USA, 2011.

63. Lura. Autogenous Deformation and Internal Curing of Concrete. Ph.D. Thesis, Delft University of Technology, Delft, The Netherlands, 2003.

64. Tazawa, E.I.; Miyazawa, S. Experimental study on mechanism of autogenous shrinkage of concrete. Cem. Concr. Res. 1995, 25, 1633-1638. [CrossRef]

65. Loukili, A.; Khelidj, A.; Richard, P. Hydration kinetics, change of relative humidity, and autogenous shrinkage of ultra-high-strength concrete. Cem. Concr. Res. 1999, 29, 577-584. [CrossRef]

66. Yiotis, A.G.; Stubos, A.K.; Boudouvis, A.G.; Tsimpanogiannis, I.N.; Yortsos, Y.C. Pore-Network Modeling of Isothermal Drying in Porous Media. Transp. Porous Med. 2005, 58, 63-86. [CrossRef]

67. Ghourchian, S.; Wyrzykowski, M.; Lura, P.; Shekarchi, M.; Ahmadi, B. An investigation on the use of zeolite aggregates for internal curing of concrete. Constr. Build. Mater. 2013, 40, 135-144. [CrossRef]

68. Zou, D.; Li, K.; Li, W.; Cao, T. Effects of pore structure and water absorption on internal curing efficiency of porous aggregates. Constr. Build. Mater. 2018, 163, 949-959. [CrossRef]

69. Lura, P.; Bentz, D.P.; Lange, D.A.; KKovler, o.; Bentur, A.; van Breugel, K. Measurement of water transport from saturated pumice aggregates to hardening cement paste. Mater. Struct. 2006, 39, 861-868. [CrossRef]

70. Henkensiefken, R.; Nantung, T.; Weiss, J. Saturated lightweight aggregate for internal curing in low w/c mixtures: Monitoring water movement using x-ray absorption. Strain 2011, 47, 432-441. [CrossRef]

71. Bullard, J.W.; Jennings, H.M.; Livingston, R.A.; Nonat, A.; Scherer, G.W.; Schweitzer, J.S.; Scrivener, K.L.; Thomas, J.J. Mechanisms of cement hydration. Cem. Concr. Res. 2011, 41, 1208-1223. [CrossRef]

72. Havlica, J.; Roztocká, D.; Sahu, S. Hydration kinetics of calciumaluminate phases in the presence of various ratios of Ca2+ and SO42- ions in liquid phase. Cem. Concr. Res. 1993, 23, 294-300. [CrossRef]

73. Richardson, I.G. The calcium silicate hydrates. Cem. Concr. Res. 2008, 38, 137-158. [CrossRef]

74. Richardson, I.G. Model structures for C-(A)-S-H(I). Acta Crystallogr. B 2014, 70, 903-923. [CrossRef]

75. Richardson, I.G. The nature of C-S-H in hardened cements. Cem. Concr. Res. 1999, 29, 1131-1147. [CrossRef]

76. Chang, J.; Fang, Y. Quantitative analysis of accelerated carbonation products of the synthetic calcium silicate hydrate(C-S-H) by QXRD and TG/MS. J. Therm. Anal. Calorim. 2015, 119, 57-62. [CrossRef]

77. Richardson, I.G.; Groves, G.W. Microstructure and microanalysis of hardened cement pastes involving ground granulated blast-furnace slag. J. Mater. Sci. 1992, 27, 6204-6212. [CrossRef]

78. Breugel, K.V. Numerical modelling of volume changes at early ages-Potential, pitfalls and challenges. Mater. Struct. 2001, 34, 293-301.

79. Juenger, M.C.G.; Jennings, H.M. Examining the relationship between the microstructure of calcium silicate hydrate and drying shrinkage of cement pastes. Cem. Concr. Res. 2002, 32, 289-296. [CrossRef]

(C) 2018 by the authors. Licensee MDPI, Basel, Switzerland. This article is an open access article distributed under the terms and conditions of the Creative Commons Attribution (CC BY) license (http:/ / creativecommons.org/licenses/by/4.0/). 